\title{
Architecture MPS
}

\section{'Le geste architectural'; Symbolism and authority in the case of the Centre Beaubourg}

Angelos Psilopoulos ${ }^{1, *}$

How to cite: Psilopoulos, A. 'Le geste architectural'; Symbolism and authority in the case of the Centre Beaubourg.' Architecture_MPS, 2018, 13(1): 1. DOI:

https://doi.org/10.14324/111.444.amps.2018v13i1.001.

Published: 05 February 2018

\section{Peer Review:}

This article has been peer reviewed through the journal's standard double blind peer-review, where both the reviewers and authors are anonymised during review.

\section{Copyright:}

(C) 2018, The Author(s). This is an Open Access article distributed under the terms of the Creative Commons Attribution License (CC-BY) 4.0 https://creativecommons.org/licenses/by/4.0/, which permits unrestricted use, distribution and reproduction in any medium, provided the original author and source are credited • DOI: https://doi.org/10.14324/111.444.amps.2018v13i1.001.

\section{Open Access:}

Architecture_MPS is a peer-reviewed open access journal.

* Correspondence: angpsi@teiath.gr

1 Technological Educational Institute (TEI) of Athens, Greece 


\section{Title: 'Le geste architectural'; Symbolism and authority in the case of the Centre Beaubourg}

\section{Author: Angelos Psilopoulos}

\section{Architecture_media_politics_society. volı.13, no.1.}

February 2018

Affiliation: Technological Educational Institute (TEI) of Athens

\section{Abstract}

Architecture seems often imbued with the notion of "gesture." The term is mentioned in abundance both when architecture is seen as a discipline and when it is seen as a social practice. Arguments about it can be found in an artefact as well as in an act of design. In this context it may be revealed as an object to be claimed (i.e., a fetish), or stand for a trace or a carrier of meaning. Thus, in a wider scope, gesture may be discussed as a persistent - if not necessary - theme in the field's culture.

This essay examines "gesture" as a mediator between society (including culture and power) and the practice of architecture. This will be discussed within the framework of the competition for the Centre Beaubourg (later known as Centre Georges Pompidou). The heated discourse revolving around the expression "le geste architectural," including the proposal to design the building literally as an open hand and thereby as a gesture of offering, will be explored. We will thus show how "gesture" simultaneously creates a multifaceted existence: at once as a token of validity and a symbol of truth and beauty, as well as representing the very danger of banality. Furthermore, we will show how the Centre itself - to which was attributed the character of a feat - becomes a "political gesture" carrying the sperm that spawned the type of "heroic architecture" that is so distinctive to the Fifth Republic. Finally, we will revisit "gesture" as a token taking part in a conundrum where the modern ideal ends up substituting genuineness with genius; and we will see this binary relationship in connection to all the "gestures" we discuss in the case of the Centre Beaubourg.

DOI:10.14324/111.444.amps.2018v13i1.001, ( ) 2018, The Author. This is an Open Access article distributed under the terms of the Creative Commons Attribution License, which permits unrestricted use, distribution, and reproduction in any medium, provided the original author and source are credited. 


\section{Amps}

On these premises we will propose that, before we ask to define "gesture" by its content, it is important to see it first and foremost for what it does; namely, that it acts as a nominator, and thereby as a mediator, and even a weaver, of the collective between architecture and society. This shift in perspective is critical, as it reveals that gesture plays a more dynamic role than any doctrine would like to have it. Ultimately, we hope to show that gesture can be seen as taking an integral part in the very fabric of architecture, instead of merely playjng a role in one of its many histories.

This essay is based on existing literature as well as original research conducted in the archives of the Centre Georges Pompidou - to which we extend our gratitude for the access. 


\title{
Title: 'Le geste architectural'; Symbolism and authority in the case of the Centre Beaubourg
}

\author{
Author: Angelos Psilopoulos
}

Architecture_media_politics_society. vol. 13, no. 1.

Affiliation: Technological Educational Institute (TEI) of Athens

February 2018

\section{Introduction}

The question of gesture is seminal. It is fundamental, inasmuch as human behaviour and argument insist on it. It is persistent, in so far as we use gesture in context, be it in direct action or metaphor. It forms part of our ontological inquiry, in the sense that it holds an important place in the process of the construction of meaning. It is ever-present, albeit cryptic, given that gesture lies ubiquitous in both action and narrative. In very similar terms, gesture is very much present in the architectural discourse through textual references in academic essays and in the relevant press. While this domain constitutes a much less epistemologically structured approach, ${ }^{1}$ it nevertheless reveals the important role that the term plays in the general understanding of architecture. On that level, gesture can be found as a prevailing narrative, ${ }^{2}$ ranging from a simple figure of speech $^{3}$ to accepted terminology, ${ }^{4}$ and extend even to a fetish. ${ }^{5}$ As such, it can also be applied to elements or actions carrying a trace, such as a symbolic hand gesture, ${ }^{6}$ a sketch conveying an architectural idea, ${ }^{7}$ or a building that is considered to "gesture" 8 to another. In most of these cases, gesture is usually connected with the notion of a fundamental condition, for example being testament to a certain fundamental truth ${ }^{9}$ or connected with a certain power of expression. ${ }^{10}$ While this domain is largely open-ended, we cannot ignore that there is an abundance of mentions of the term, which we will attempt to address here by focusing on the specific case study of the Centre Beaubourg. In this regard, we will consider gesture solely in its role as a mediator between an architectural concept and the practice of architecture within society, leaving attempts to a more complex and wider theoretical framework for other occasions. ${ }^{11}$ It is important, however, that the reader considers first a general shift in perspective; namely, that before looking to 


\section{Amps}

define "a gesture" by its characteristics as an object, one should consider that gesture in general tends to take an active position in the discourse by nominating the subjects of a collective, that is, by assigning identities to those who partake in the discourse around it. In this context "gesture" weaves the collective, assuming therefore a quasi-active role $^{12}$ as a mediator between the practice of architecture and society (including culture and power).

What is a gesture, then? In terms of framing our argument, the study of gesture per se ranges from a deliberate expression of rhetoric ${ }^{13}$ to a spontaneous utterance of thought. ${ }^{14}$ The case is no different with architecture, where mentions of gesture can be found either in the everyday language of architecture ${ }^{15}$ or within the activity connected to the field. ${ }^{16}$ The study of gesture ranges accordingly, to encompass a similar level of diversity; Noam Andrews ${ }_{17}^{17}$ for instance, examines the aspect of gesture in the hand drawings of Classicism from the Renaissance onwards, and proposes it as a conduit of corporeality and a sign of the "autoritas" of the architect, at the same time that Visser and Maher ${ }^{18}$ examine it as an actual cognitive activity, studying the communication patterns in architectural design meetings. Moving to the actual building, Ákos Moravánszky deems it appropriate to present us with

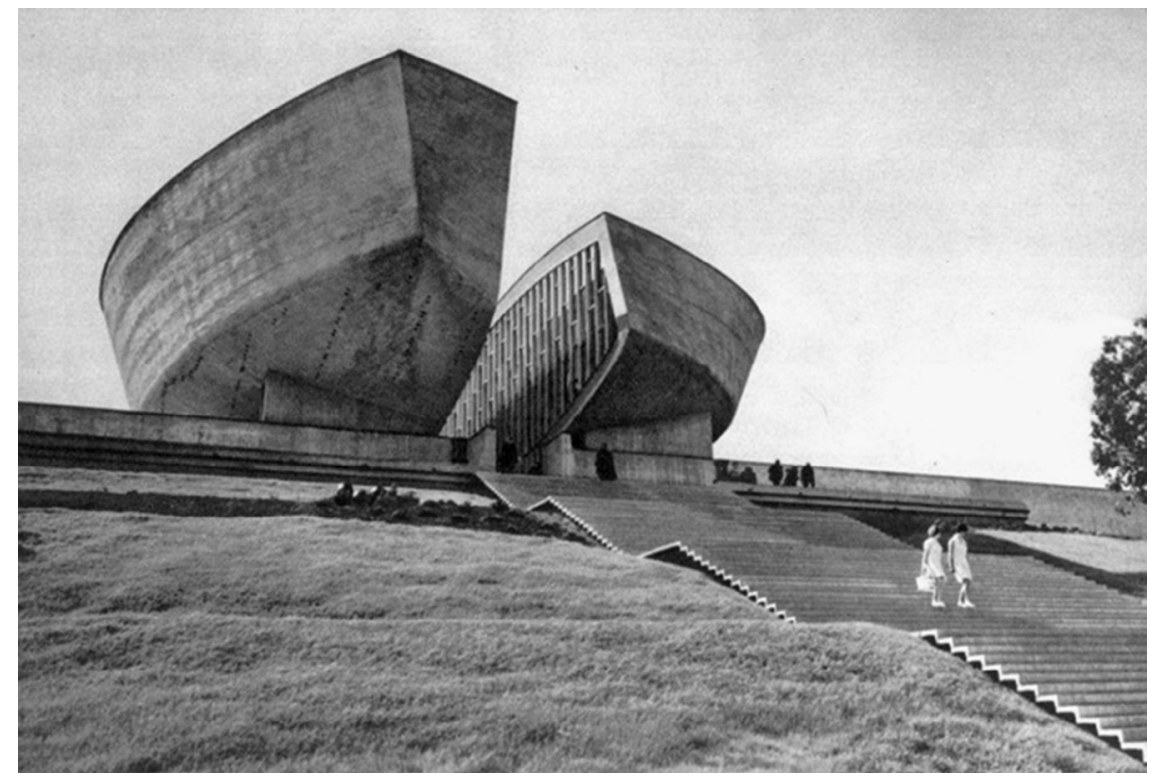

Figure 1. Museum of the Slovak National Uprising in Banská Bystrica,

Photo by Karel Plicka (c. 1950). ("Four Photographs of Czech and Slovak

Modernist Structures by Karel Plicka," The Serendipity Project, December 6, 2011. https://serendipityproject.wordpress.com/2011/12/07/dec-7-2011-four-photographs-

of-czech-and-slovak-modernist-structures-by-karel-plicka-c-1950s/ accessed

November 23, 2017) 


\section{Amps}

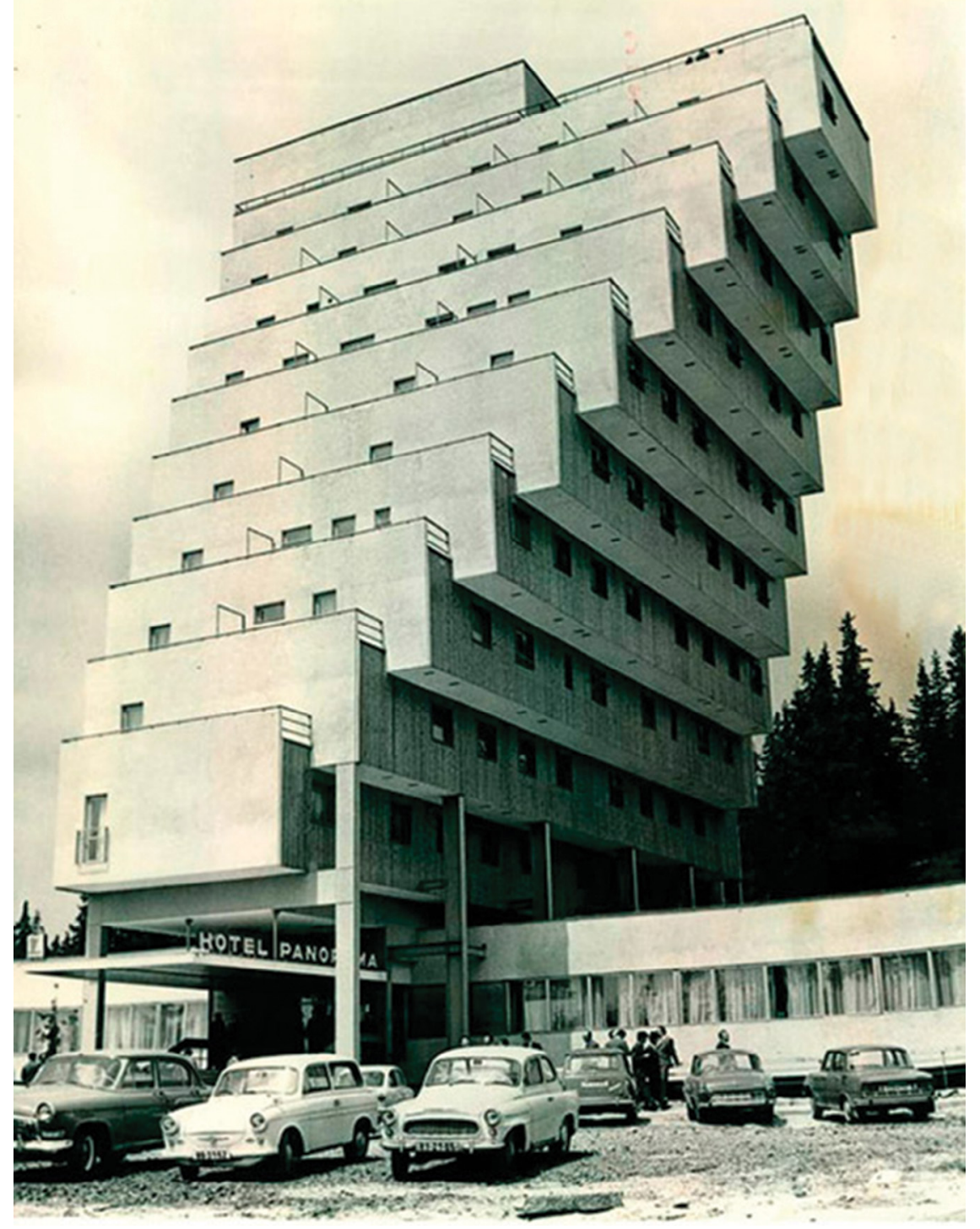

Figure 2. Slovakia, Strbske Pleso, Panorama Hotel Ski Resort. (Rossiyskaya Gazeta. "Relics of Constructivist Architecture in Post-Soviet Countries" Russia beyond the Headlines, August 21, 2013 http://rbth.com/multimedia/pictures/2013/08/21/ relics_of_constructivist_architecture_in_the_former_ussr_29093/ accessed November 23, 2017) 


\section{Amps}

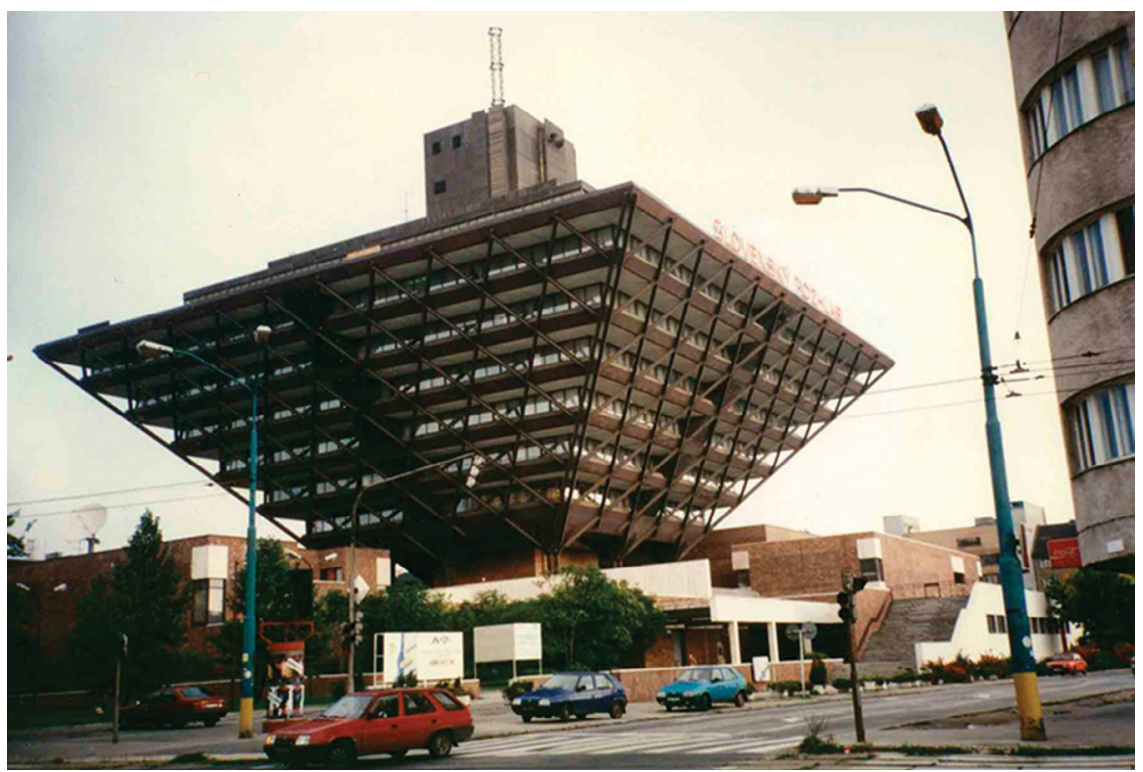

Figure 3. Czechoslovakia, Bratislava, 1983, Slovak Radio Station; designed by Stefan Svetko, Stefan Durkovic and Barnabas Kissling. (Ibid.)

the notion of a "grand gesture" 19 connected to the kind of expressionist architecture that prevailed during the $60 \mathrm{~s}-70 \mathrm{~s}$ in the socialist nations. In this case "gesture" refers to a certain abstract formal mannerism that prevailed against the symbolist tradition of the classicist monuments - the latter being representative of an era that the new regime aimed to supersede. In this occasion, "gesture" is attached to the "acrobatic" quality of the new style, showcasing the communicative power of architecture as it carries the grandiose expression of political will, but also, as it stands for the desire of the architects to submit the laws of nature to their own formalistic explorations.

Along the same line, one of the most unapologetically ubiquitous expressions that carry the notion of a "gesture" into the discourse about architecture can be found in the French phrase "le geste architectural." Taken literally, it actually translates into "an architectural gesture." ${ }^{20}$ nevertheless, in the context of the French culture it is not so much a reference to formal expressiveness, but rather a reference to the core idea or principle of an architectural project - the parti. Hence, the "geste architectural" represents a condensed capacity of expression as a sort of design "event" that sums up the principal quality of a building in a single instance. More interestingly though, once gesture takes the form of an act, it is also often understood as a feat or an exploit. ${ }^{21}$ This is a meaning that largely originates from the word's medieval roots, ${ }^{22}$ and through which the phrase "geste architectural" is seen as implicitly bound to an act of architecture that serves as an expression of power, for 


\section{Amps}

example by a prevailing elite, either architectural or political. ${ }^{23}$ All of these instances - as we shall see later on - play a major role in the case of the competition for the Centre Beaubourg. ${ }^{24}$

\section{The Competition of the Centre Beaubourg}

Architecture, always in need of an "Archē-" - a beginning, ${ }^{25}$ can potentially fetishize "gesture", sometimes to the extent of compulsive fixation. This aspect was portrayed explicitly in the case of the Competition for the Centre Beaubourg, ${ }^{26}$ where the laureate scheme was famously attacked by a group of disenfranchised architects self-proclaimed as "L'Association du Geste Architectural," specifically for lacking the truth which "le geste" stood for. At the same time, the very constitutional philosophy and political will behind the scheme saw in "gesture" quite the opposite: "le geste architectural" was deemed the very carrier of banality that the Centre should aspire to escape at all costs. Thus, a fiery debate arose between the advocates of the latter and the "association" - and especially their president, André Bergerioux - over the architectural quality (or lack thereof) that the competition advocated. In a public communication to the "Nouvel Observateur," ${ }^{27}$ Bergerioux promoted the significance of the "geste architectural" as he supported the group's intention to fight the good fight:

The "geste architectural" conveys the logic and the sentiments of the architect through a trace in space. It gives the project its character. A project lacking such a gesture is not a work of architecture..$^{28}$

And he continued ${ }^{29}$ in protest,

We must consider that it is for the worst reasons in the world that citizens of all professions and all social backgrounds have assembled into one association, so called the "Geste Architectural", out of their concern before an official body confessing its allergy for architectural gestures and placing its only confidence on the technique and the programming ${ }^{30}$ intended to create the mold for the robot-human of the age 2000. Must we have a man adapt to [such a] progress, founded on the "golden calf" of the economic process of production and consumption? Must we also enslave man to the machine in order to serve this ideal, protecting [thus] th[is kind of] architectural pollution? ${ }^{31}$

In these few lines, Bergerioux sets the "truth" of gesture against a machinist future where culture is meant to be consumed rather than created, and thus de-humanized in view of its capacity to be capitalized by the prevailing powers.

Nevertheless, as we mentioned earlier, the circumstances around the Competition for the Centre Beaubourg made it hardly a simple incident of dispute. Critically attached to its patron, President Georges Pompidou, the 


\section{Amps}

project was first and foremost a reformist venture, meant to attack established preconceptions about the role of culture in French society, the function of an institution, and, by extension, the architectural quality of a building. Most importantly, it was meant to be Pompidou's answer to a battle between two prevailing impressions of culture: a conservative one, serving the elitist tastes of the past and the "historic greatness" of France, and a progressive one, promoting fiercely a reform through which cultural heritage was meant to be created anew, and diffused democratically to the widest possible audience. ${ }^{32}$

In regard to the building itself, a series of steps was taken to emphasize the avant-garde nature of the scheme. For one, it was the unprecedented nature of its program, aiming to substitute the traditional museum with a contemporary building equal to or better than its international counterparts, reflecting the values of multidisciplinarity, plasticity, and the dissemination of culture. Under this brief, the Centre was intended to shelter not one but multiple cultural functions under the same roof: a public library, the "National Museum of Contemporary Art" (Musée National d'Art Moderne - MNAM), and the "Center of Industrial Creation" (Centre de Création Industrielle - CCI), with the later addition of the "Institute for Research and Coordination in Acoustics/Music" (Institut de recherche et coordination acoustique/ musique - IRCAM). ${ }^{33}$ The very modern notion of programming ${ }^{34}$ became central to the organizing committee led by Sébastien Loste and 30-year-old François Lombard, which was appointed to develop the scheme under a new, systems-driven approach. Constant to the narrative of integrity and democratization, this program was famously developed in continuous consultation with a group of "utilisateurs," comprised of the future directors of the institutions who were going to be posted in the Centre once it was finished ${ }^{35}-\mathrm{a}$ consultation that was going to be maintained even after the laureate project was announced, and until the final realization of the building.

Finally, with regard to assigning an architect for the project, Georges Pompidou had opted to hold an international ideas competition instead of a direct commission. According to Laurent Fleury, Pompidou had done this for the same reasons: to signal the rationality and the democratization of the process by opening access to an international scene, as well as to young and unknown architects, safeguarding it at the same time from the arbitrariness of his presidential powers. ${ }^{36}$ Substituting for a single and undisputed authority, a Jury was assembled, composed of figures of international stature, "mediating between the political leadership (with which they had personal relations) and the world of creators." ${ }^{37}$ These were architects Philip Johnson and Oscar Niemeyer; architect Emile Aillaud, well renowned for his work with social housing in the périphérie; Frank Francis, director of the British Museum; Michel Laclotte, director of the department of paintings at the Louvre; William Sandberg, former director of the Stedelijk Museum in Amsterdam; and Herman Liebhaers, ${ }^{38}$ director of the Royal Library in Belgium and Gaétan Picon Professor of Philosophy, literary critic, and former director of Arts and Letters at the Department of Cultural Affairs. The position of 
the chair was awarded by election to Jean Prouvé, an engineer by training but widely accepted for a career which exemplified "a fusion of Arts and the Industry." ${ }^{39}$ True to President Pompidou's reformist agenda, this Jury not only consisted of people of gravitas, but also of figures who were attached to similarly progressive schemes from around the world. ${ }^{40}$ And, of course, the selection of Jean Prouvé - whose adherence to the technical qualities of an œuvre was well renowned - must have signalled an alarm call to all those who cherished the aestheticized values of the old masters.

Far from assigning the building directly to a "maitre" architect, these directive lines "forged the base for the "esprit Beaubourg" 41 as a more universally reformist scheme, which ultimately "opposed [italics mine] (...) the singular 'geste architecturale' so dear to the formalist school." ${ }^{42}$ According to the recollection of Herman Liebhaers, Jean Prouvé expressed openly this position as he addressed the Jury: "Messieurs, j'espère que nous sommes tous d'accord pour éviter le geste architectural" (Gentlemen, I hope we are in agreement to avoid the architectural gesture). ${ }^{43}$ Under these circumstances, the building was partly created as a battleground between a formalist agenda and the new avant-garde, a battle already taking place in France with the 'utopian' visions of the $60 \mathrm{~s}$ and the $70 \mathrm{~s} .{ }^{44}$ With a Jury set outright to fight against the perils of banality, ${ }^{45}$ chances would be bleak for the "[f]ifty projects - that is to say a strong enough minority ${ }^{46}$ - [which] were characterized by an aggressive search of geometric shapes or provocative sculptures aimed for the spectacular, the dramatic or the majestic." 47 Although the Jury almost always immediately eliminated - and always in unanimity - "these spheres and these cubes, these conical trunks and these cylinders, these pyramids, reversed or not, these giant ovoid forms, regardless of whether they were, overall, perfectly constructible", this was not meant as an opposition to any solution that was expressed by simple geometric elements, "as the choice of some of the laureate projects, including the winner, testify," 48 but rather against the perils of gratuitous monumentality. The Jury famously asserted

[that] if the freedom of the architectural forms must be encouraged, this freedom cannot be simply formal; that a "monument" which would have no other function than to express an architectural "gesture" is vain; that emphasis is eloquence and that art for art's sake can be the opposite of the art. ${ }^{49}$

In this spirit of progressiveness, "gesture" became once again a token concerning which a fight was meant to be fought, even though this time it stood for a negative connotation.

Interestingly enough, such an - almost literal - gesture-of-a-building was submitted by Bergerioux, ${ }^{50}$ who proposed to build the Centre in the shape of an open hand (!), elevated over a rectangular base. Functionally, the project consisted of three zones: the underground level which would serve mostly for auxiliary functions, including parking and access to the metro; the ground level, assigned as a public access area and a promenade, hosting also the 


\section{Amps}

permanent and temporary galleries, the library, "public meeting spaces" including a cinema theatre, a dance hall, and multi-purpose halls; and finally the "hand," conceived as a Museum of Modern and Contemporary Art, which would encompass "painting", "sculpture", and "design", under one roof. The hand was supported on four oversized cylindrical pilotis which also doubled as access areas. This sculpture-building ${ }^{51}$ was not merely meant to act as a "symbol of unity" between the different functions of the Centre, but also to act as testament to the overarching authority of "an idea" over the trivial aspects of the program. The principles of Bergerioux's proposal were described on a quite telling "Exposé" attached by requirement to the submission:

To design a cultural center is, without doubt, to meet with certain material requirements but it's mostly about putting matter in the service of an idea. (...)

More than a mere building, this project wants to be a monument. If the general shape of the central element is reminiscent of a hand, it is (...) because of its symbolic value - since probably all creation must pass through it - but also because of its sculptural beauty. What other form could better translate the unison between the multiple forms of creation?

But a symbol can be cold. It must be animated. It is the trees and plants, integrated to the architecture and the works of artists, that give life to the center. (...)

A sculpture above the water, on a base of greenery; suchis the answer that the matter gives to the question posed by the philosophy of the centre Beaubourg. ${ }^{52}$

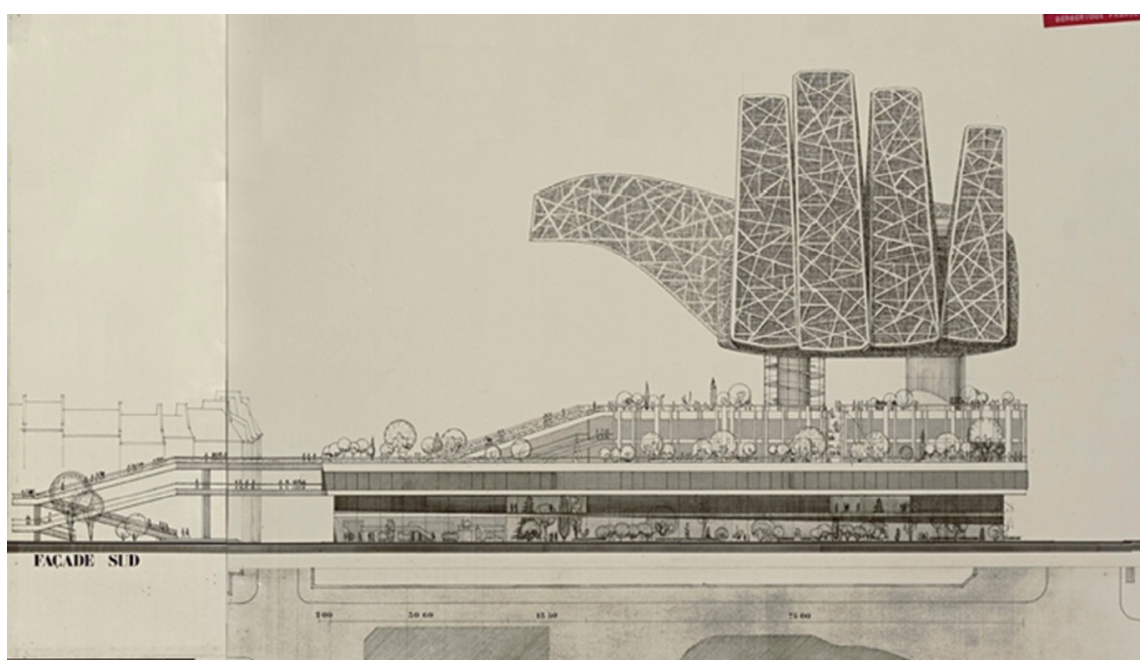

Figure 4. Bergerioux, André. Project No 006; South façade. (Submission. Concours International d'idées pour la Réalisation du Centre du Plateau Beaubourg. Paris: Délégation à la réalisation du Centre du Plateau Beaubourg, 1970. 1992037/016 (Juillet 1971); Dossiers des projets.) 


\section{Amps}

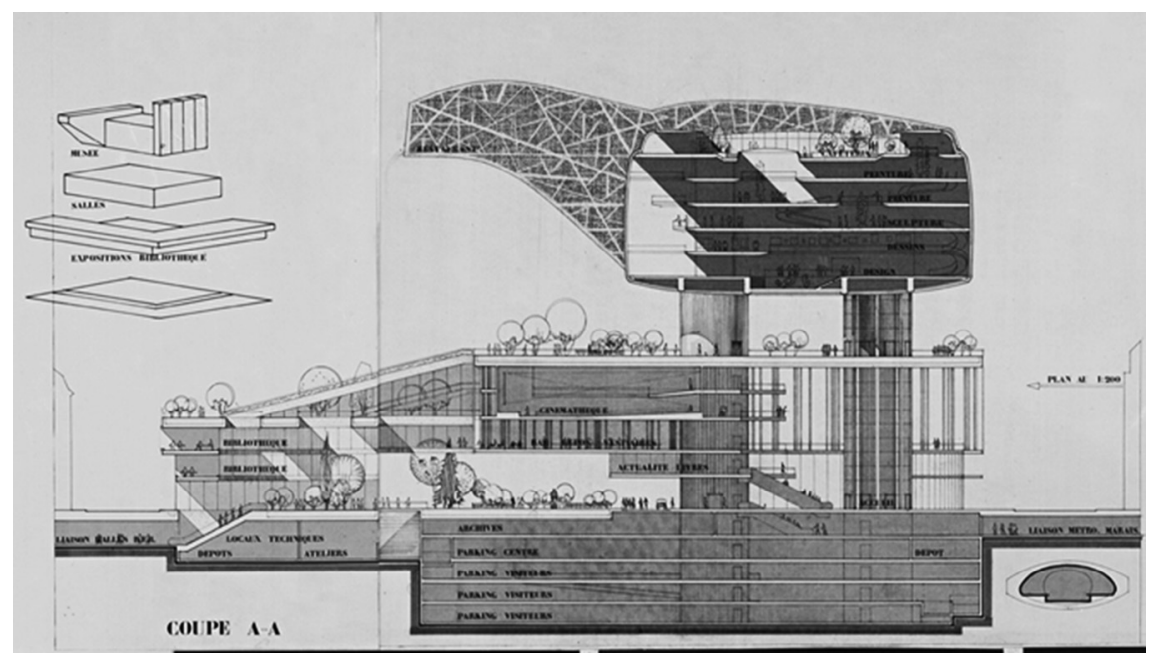

Figure 5. Bergerioux, projet 006. Section A-A. (Ibid.)

This overwhelming iconicity obviously bears strong resemblance - if not testament - to the proposal for an Open Hand monument in Chandigarh, India, by Le Corbusier. ${ }^{53}$ One can be tempted to an enticing correlation with Bergerioux's proposal, if only for the idealism attached to the project, but also on the grounds of the strong resemblance of the building's shape and layout to the monument. In fact, the principal logic seems to be entirely corresponding: the overarching icon of an open hand, standing on a column, overarching a plateau where people will assemble in unity.

It is most likely that Bergerioux may have been influenced by the Maître on the occasion of the competition. ${ }^{54}$ Le Corbusier himself was prone to a certain tendency towards obscure iconographic references in his later career, for example as manifested in the chapel at Ronchamp (1950-54), among which the hand of Chandigarh is a notable example; therefore it would be enticing to assume that his 'school of thought' had carried over. In the same context, it is also interesting to consider the atmosphere charged by the maitre's recent death (1965), combined with the posthumous publication of his Mise au Point (1966) - a book largely written in an emotional language which had presented the Open Hand monument as carrying the culmination of his personal obsession with the theme ${ }^{55}$ at the same time that it described the maitre's futile battle to fund the scheme. ${ }^{56}$ Finally, we can also take into account that it was Le Corbusier who was originally entrusted with the idea of a "Museum for the Art of the 20th century" in Paris, out of which had spawned the project for the Centre Beaubourg, and that it was in fact Le Corbusier himself who had publicly advocated the integration of the new complex "in the heart of the city", ${ }^{57}$ not long before his death. Overall, the monument in Chandigarh offered exceptional parallels to the case of the Centre Beaubourg because 


\section{Amps}

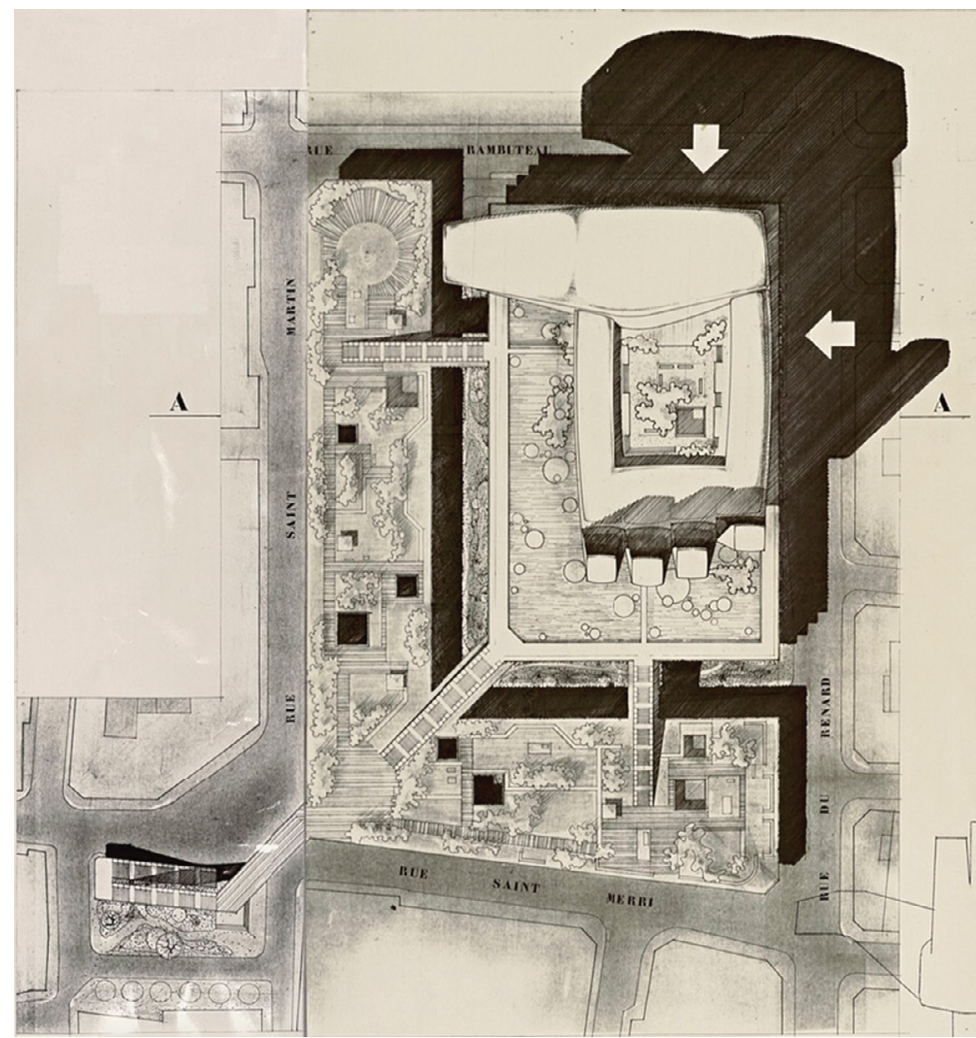

Figure 6. Bergerioux, André. Project No 006. Aerial Plan. (Ibid.)

it was also proposed for an already contextually charged space, ${ }^{58}$ and also because it was meant to transcend the general programmatic aspirations of the new capital through the power of its symbolism. ${ }^{59}$

However, contrary to the - potentially - sentimentalist aspirations of Bergerioux and the like, Centre Beaubourg was never meant to pay tribute to the old masters. ${ }^{60}$ On the contrary, it was intended to express a generation which had manifested itself abruptly in May '68 and had decided to do away with anything connected with a conservative and elitist past. ${ }^{61}$ This new utopianism had found a perfect ally in the progressive narrative of President Pompidou, underlined by the way it was carried by the technical committee and served faithfully - if not enthusiastically - by the Jury. The President explained his reasons in an interview with Le Monde: "I am baffled by the conservative character of the French taste, particularly of those considered as 'the elite', [and] scandalized by the politics of the Public State on the subject of art for over a century; this is why I am looking to react, [albeit] with limited success". ${ }^{62}$ When asked about the dimension of conflict between novelty and 


\section{Amps}

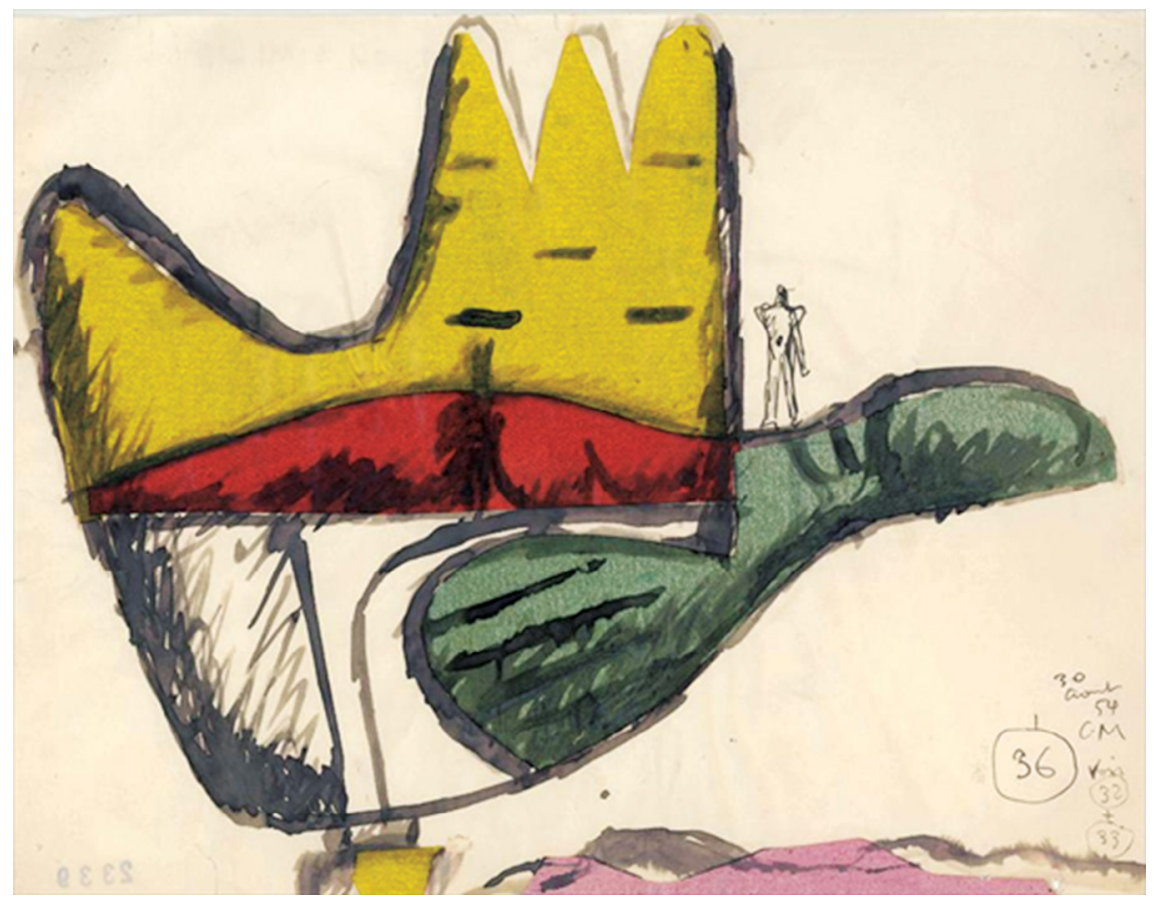

Figure 7. Le Corbusier, Sketch for the Open Hand. C FLC/ADAGP

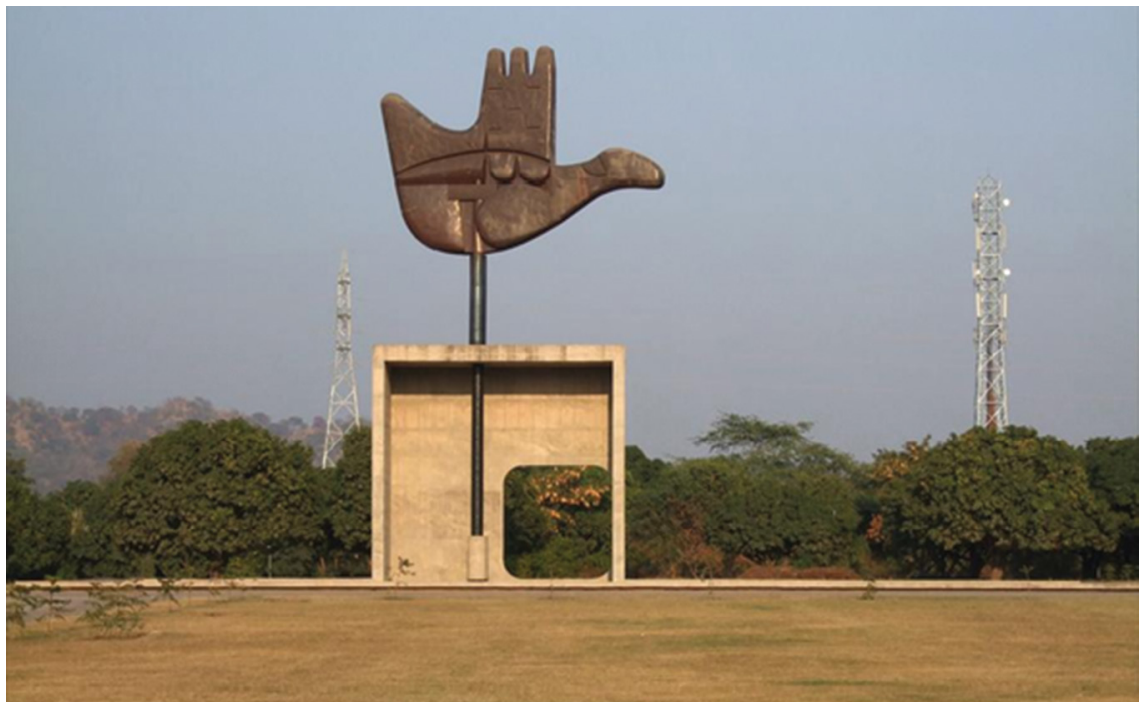

Figure 8. "Main Ouverte", Chandigarh, India. CFondation Le Corbusier (FLC) / ADAGP. Available at http://www.fondationlecorbusier.fr/ 


\section{Amps}

patrimony, ${ }^{63}$ Pompidou pointed to a truly Modern monument ${ }^{64}$ in no uncertain terms:

The question is not new! You are aware of the verse of Baudelaire:

Le vieux Paris n'est plus, la forme d'une ville

Change plus vite, hélas ! que le cour d'un mortel. ${ }^{65}$

We can't stay fixed in the past. Paris is not a dead city; it is not a museum to maintain. The builders - from Louis XIV to Haussmann - destroyed much more than they built. The Roman Middle Age has built its churches, [and] Renaissance its palaces, with the stones of ancient monuments. I do not consider this as a model to follow - far from it. (...) But we act on the principle that we must accept novelty, and simply try to search what makes it beautiful and not a copy of the past. ${ }^{66}$

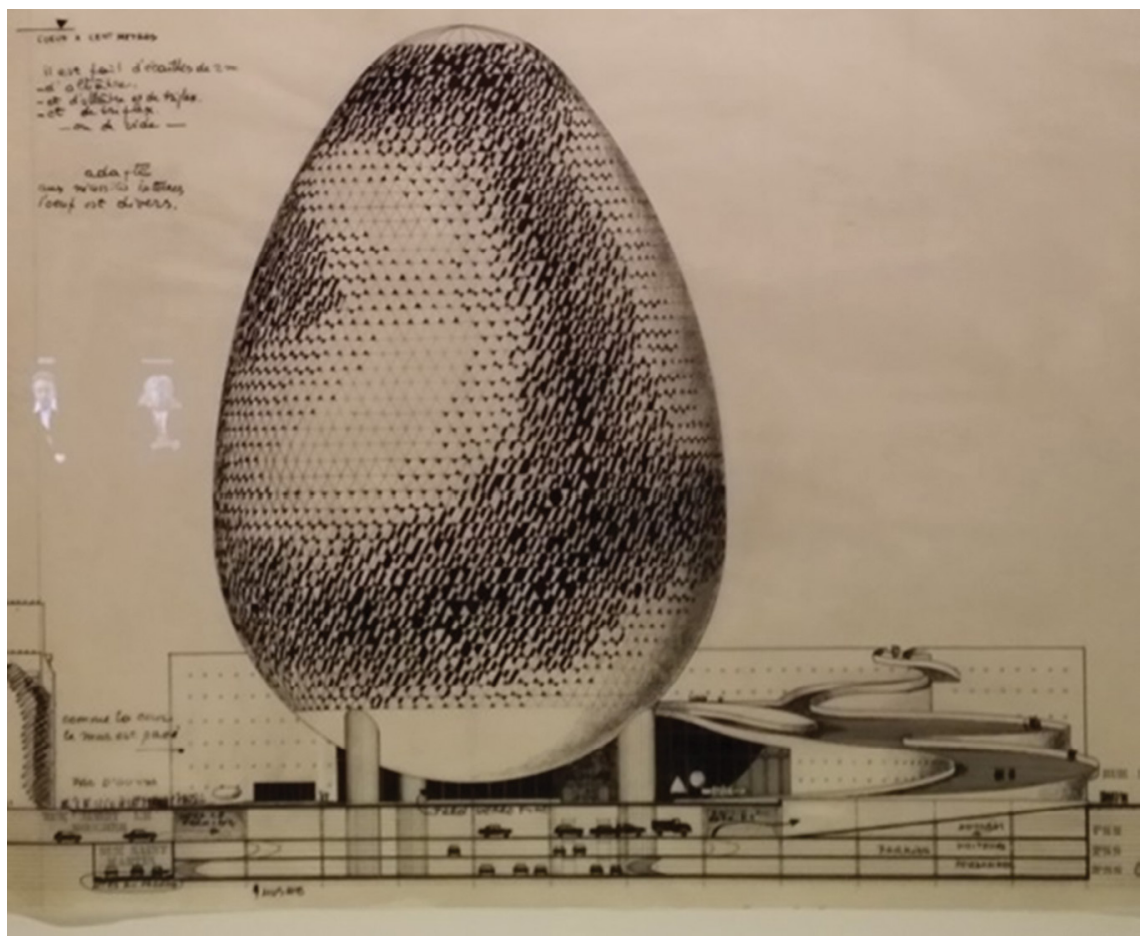

Figure 9. André Bruyère [France], 1971. Project $n^{\circ} 272$. The project was marked with an "A" by at least one member of the Jury during the first phase of the competition (7/7/71), which made it immediately eligible for a full review by the rest of the Jury. According to the notes available, the project was eliminated after the second review (12/7/71). (Chaslin, François, and Eve Roy. André Bruyère : La Tendresse des Murs. Paris: Editions du patrimoine, Centre des monuments nationaux, 2016.) 


\section{Amps}

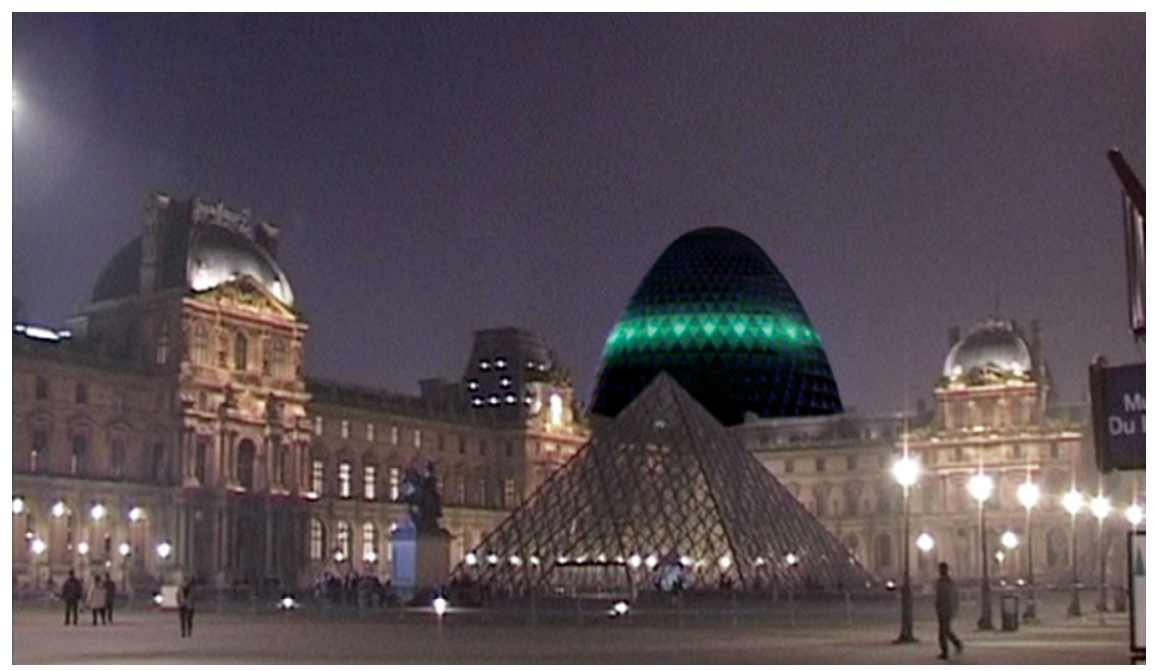

Figure 10. Outtake from an experimental project integrating André Bruyère's "oeuf" into the Parisian landscape. Some associations can be drawn to Foster and Partners'

Swiss Re building in London. (Arnold, Jens. L'œuf de Pompidou. Video, 2003. http://aii.ensad.fr/projet.php?id=94)

It is evident in these lines that Pompidou considers it an imperative to act personally, and take it upon himself to safeguard the vision of a contemporary version of culture. This is the point where the project becomes a personal feat: for something so connected with narratives of impartiality, democratisation, and a radical break with the past, we see that it still takes a single man's vision to achieve what would otherwise be buried in endless conversations on value, aesthetic quality, administration, politics, etc. This aspect is highlighted in almost every piece of literature concerning the creation of the Centre, ranging from positive accounts of the President's involvement ${ }^{67}$ to the graphic characterisations, such as "the Pompidoleum" 68 and the related caricatures in the press. ${ }^{69}$ But it is the apostrophe of Claude Mollard, which sums this "geste politique" - an administration ("gestion") as well as an achievement of personal will ("geste") - most concisely: "A l'origine d'un acte architectural, surtout s'il s'agit d'une institution de grandes dimensions, il y a nécessairement la décision d'un pouvoir, voire même d'une personne." 70 As the President used to say jokingly, "[sometimes] you [just] have to shout!"71

\section{Conclusion: taking "gesture" for what it does}

As we saw in the case study of the Centre Beaubourg, "gesture" seems to take multiple values at once, both positive and negative. In this regard it is fundamentally difficult to agree on what gesture $i s$, unless we are prepared to pick a 


\section{Amps}

side and defend our position. Nevertheless, we can still see the themes of genuineness and authenticity running through as a common thread. Quite appropriately, W. Flusser argues that gesture acquires its meaning less through the information it carries and more through the affective process it initiates. ${ }^{72}$ As Gänshirt notes, reading into Flusser's analysis:

[I]n order to determine the truth of gestures (...) they should not be judged by ethical or epistemological criteria, but by aesthetic ones: the question is not whether a gesture represents truth or lie directly, but the extent to which whatever it represents is truth or kitsch. ${ }^{73}$

In a similar manner, Bart Verschaffel's essay "Architecture is (as) a gesture"74 uses "gesture" as a metaphor in order to elaborate on the modernist anxiety between tradition and novelty. In place of Moravánszky's formalist gestures, Verschaffel juxtaposes two quite different models of "gesture." The first is common, familiar, like a simple greeting: an action that everyone knows how to perform, and does so almost unknowingly, naturally, without any preoccupation about its form or shape. The second is that of the modern individual: once prohibited from referring to any given form of the past, the modern individual must necessarily create the form anew. Crossing over to an act of architecture, Verschaffel attaches the first gesture to the "authentic" house such as a peasant would build. As Henry van de Velde puts it, this house is representative of the modernist ideal by merit of its honesty and unpretentiousness. ${ }^{75}$ According to van de Velde, these two qualities must serve as testament to the truth and genuineness of any new act of architecture. As such, they also establish an argument against all attempts to imitate the past. But this is exactly the problem with modernity: once set against any imitative reference, it must necessarily reinvent the qualities of honesty and unpretentiousness, thus creating the peasant's house anew. This proves to be a Herculean task, once the threat of novelty is immediately connected to a flurry of individualism. As van de Velde remembers it in his Pages de Doctrine,

[w] ithout grand gestures, without great pronouncements, the "Arts and Crafts" group, around 1894, knocked down the doors by which - as soon as the creations of this English group became known on the continent - a torrent of individualists would break free who, carried along by the frenzy of their reclaimed liberty, by the joy of having swept away the nightmare of the imitation of styles, would for a certain time cease respecting anything that resembled a discipline, or measure, anything that might have threatened to hamper this freedom. $(\ldots)^{76}$

(...) The threat of novelty has remained constant. So long as it is not put off, it will extend not only the decadence of taste indefinitely, but it will demoralize all those having directly or indirectly to do with creation. ${ }^{77}$ 


\section{Amps}

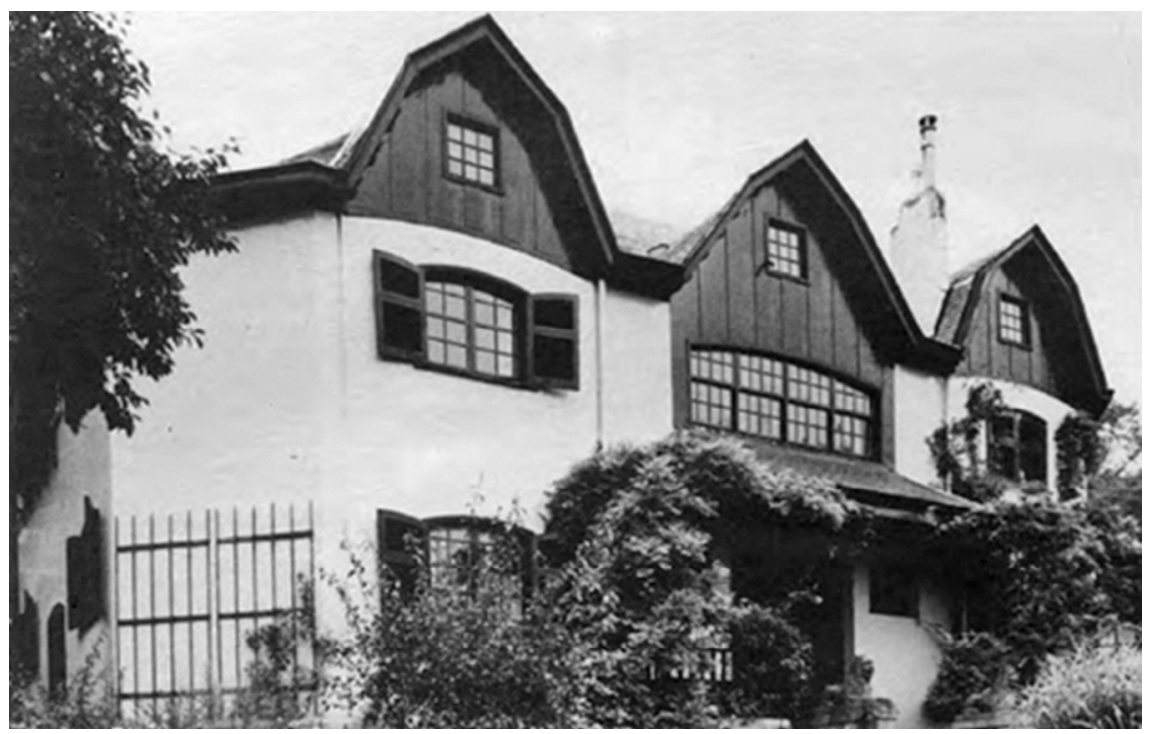

Figure 11. Henry van de Velde, the 'Bloemenwerf' house, in Uccle-Bruxelles, 1895. The forms are indicative of the direct influence English Country houses had on the artist. (Bekaert, Geert. "L'influence de Viollet-Le-Duc Sur L'architecture

En Belgique et Aux Pays-Bas Vers 1900.” Translated by Willy Devos.

Septentrion, 1985.)

According to Verschaffel, this double-edged conundrum is to be resolved like a Gordian knot. Lacking the unpretentious honesty of the ignorant peasant, the modern individual must substitute genuineness with genius:

Opposed to deceitful formality (...) there is 'genius' or, in its later, democratic version, spontaneity. Genius is real and authentic, or - in a reduced version - : the spontaneous or informal is real and authentic. ${ }^{78}$

In this observation, Verschaffel pinpoints the very pathogeny of mediating authenticity through self-expression.

The genius, the artist, the poet tries to 'speak anew' and to make - from the heart, in sudden burst of creativity - original forms that are the same time very personal and immediately (...) universal, generally human, eternally accessible. In the best case the strategy works, in the worst and most common cases one makes a spectacle of oneself and only a highly inflated ego appears. ${ }^{79}$

By this iteration of authenticity, the self is glorified instead of excluded. But in these terms, each attempt to 'create anew' also becomes a test of accreditation, of the self as well as the form, subject to either success or miserable 


\section{Amps}

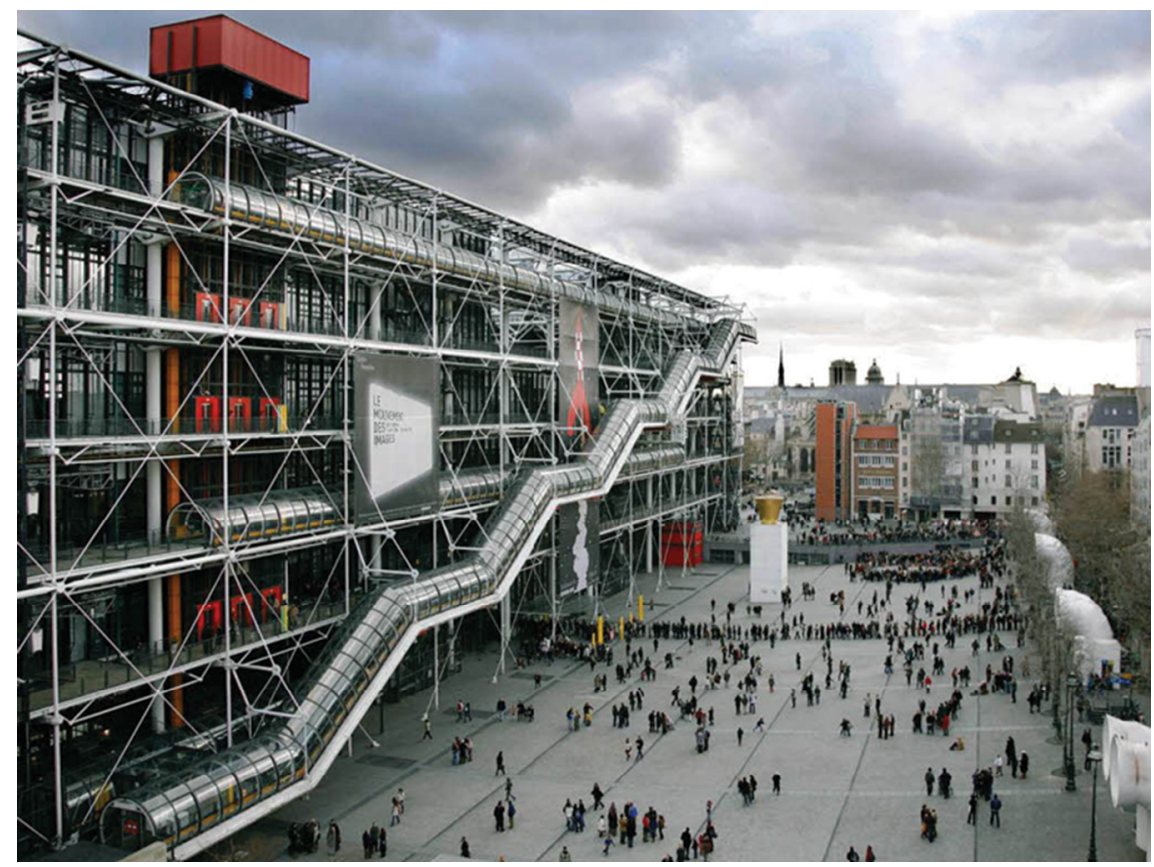

Figure 12. The architects respond to the requirement of polyvalence and plasticity by offering an interior completely empty of its internals. All the service and mechanical systems are transferred in one swooping move to the outside exoskeleton of the building. (estudio campo baeza. Centro Pompidou. Renzo Piano Y Richard Rogers. Photo, October 26, 2012. https://www.flickr.com/photos/campobaeza/8125299099/)

failure. Should we revisit then our case study on these terms: do we ascribe to Bergerioux's assertions that the Centre Pompidou is lacking a "gesture" or do we acknowledge a gesture of genius as, in a swooping move, the building reinvents the design brief it was meant to serve? Do we see, in a turning of the tables, Bergerioux's hand-like building fit to stand proudly against Le Corbusier's monument in Chandigarh, or do we see it as a failed attempt to reproduce its symbolic power? In the end, we find ourselves completely immersed in Flusser's argument: deciding on gesture may very well be subject to an aesthetic judgement.

However, taking everything into account, this judgement is hardly a final answer as to what a gesture is. As we saw in the case of the competition for the Centre Beaubourg, a number of arguments were made on both sides of the dispute. The positive or negative understanding of the term "gesture" was substantiated depending on the viewpoint one took when discussing it. Still, several traits, such as "authenticity" and "empowerment" seem to persist, depending on the manner in which one examines the term. For example, we see how, in spite of the professed intentions of the committee and the Jury 


\section{Amps}

of the competition against an aestheticized formalist "geste" (according to Moravánszky), the whole venture ultimately gave way to a majestic - and equally subject to aesthetic judgement, philosophically speaking - "geste politique", which subsequently spawned numerous architectural interventions of a large-to-monumental scale that characterised the Fifth Republic up to date, ${ }^{80}$ and reinvigorated the old ideal of "le mécénat d'Etat" ${ }^{81}$ Moreover, we can also see how the singular and ground-breaking presence of the laureate scheme actually turned it into an icon ${ }^{82}$ despite the fact that the Jury was determined not to have 'a monument' in the first place. Finally, we see how the architects' idea to take the notion of polyvalence as a parti and empty the entire building of its interior, including all the service systems, has established itself in the textbooks of architectural history as 'speaking anew', one genius expression of architecture and a veritable "gesture", one may argue in accordance with the reasoning offered by Verschaffel and the like.

Therefore, it is evident that characterising an act of architecture as a "gesture" can be a very difficult thing to achieve in absolute terms. As we mentioned at the beginning, "gesture" itself lies ubiquitous in act and language; and it seems that is also true regarding architecture. However, if we take a wider view on the arguments we offered in this essay, we see that "gesture" appears to be a persistent factor, not by merit of its capacity to designate "good" architecture and distinguish it from "bad," but rather by being the token by which histories are being woven. Thus, we suggest that, in spite of the various common themes and traits that are certainly discernible in the cases we examined, it is important to see gesture first and foremost for what it does instead of what it is. Once we do that, we perceive that the role of "gesture" may simply be that of a mediator between architecture and society, carrying the weight of the content we ascribe to it and actually generating the terms of the discussion that revolves around it. Such a concept may well be rooted in sociological and philosophical aspects as, for instance, in the Actor-Network theory, ${ }^{83}$ where the question about what something is turns into how does something take part in a dynamic relational system. We could then use the term "quasi-object" 84 coined by the French philosopher Michel Serres to designate the function of a 'thing' that stands ontologically between an object and a subject, and whose attributes bear little significance compared with its function. Paraphrasing Serres to fit our argument, "gesture"

is not an object, but it is one nevertheless, since it is not a subject, since it is in the world; it is also a quasi-subject, since it marks or designates a subject who, without it, would not be a subject. ${ }^{85}$

Given the variety of iterations that we saw gesture take in the case studies that we examined, this description looks indeed quite appropriate, as the role of gesture may equally turn out to be that of an actual object, a symbol, or a fetish (i.e. an object), as well as that of a nominator that designates a 


\section{Amps}

good architect against a bad one (i.e. a subject). Ontology aside, however, it is equally important to see here that in all cases, "gesture" keeps reflecting a social bond, a shared position, a Gadamerian "sensus communis" 86 which also reflects a space of community. Or, as Anne Cauquelin is keen to notice, "a 'lieu commun' (a commonplace) (...) [which] is also always a 'lien commun' (a social bond)." ${ }^{87}$ In these terms, gesture may very well be regarded as a weaver of inter-subjectivity, the nature and fabric of the bond reflecting the very properties of gesture itself - at one time a formalist venture, and at another time a feat.

In conclusion, the question of gesture in the context of architecture seems to be far more a methodological problem, than a heuristic inquiry. This is an important aspect to follow, since architecture itself is far more prone to doctrine than to argumentative statements. At the same time, most types of methodically substantiated claims about gesture so far consist mainly of historical evidence - such as the one[s] we examined here - or grounded cognitive research on actual gestures examined at face value as a communicative interface. ${ }^{88}$ However, this does not address a more general inquiry on the fabric of architecture itself, but rather stays confined within a preconceived hypothesis about what gesture is, which also reflects a preconceived hypothesis about how architecture stands as a research framework for the specific question at hand. Therefore, we suggest that there is merit in our findings, if anything because the shift of perspective it requires allows us to investigate our questions in a more open-ended way. In such a view we maintain that both gesture and architecture preserve their dynamic, and even entropic, nature as a free-forming human endeavour, and are left open to be discovered in the full richness of their nuances. This argument supports the notion that gesture may very well be part of the fabric of architecture as we know it. And it appears like ubiquity is the first and foremost attribute a researcher should look to preserve when dealing with such a fundamental concept.

\section{Notes}

1 Mostly limited to the domain of textual analysis. See, e.g., Norman Fairclough, Analysing Discourse: Textual Analysis for Social Research (London; New York: Routledge, 2003); Alan McKee, Textual Analysis: A Beginner's Guide (London, United Kingdom: SAGE Publications Ltd., 2003), http://srmo.sagepub.com/view/ textual-analysis/SAGE.xml; Satu Elo et al., "Qualitative Content Analysis," SAGE Open 4, no. 1 (January 1, 2014): 2158244014522633, doi:10.1177/2158244014522633; Justin Grimmer and Brandon M. Stewart, "Text as Data: The Promise and Pitfalls of Automatic Content Analysis Methods for Political Texts," Political Analysis, January 22, 2013, mps028, doi:10.1093/pan/mps028; Joseph M. Moxley, "Textual Research - Writing Commons," accessed July 3, 2014, http://www.writingcommons.org/open-text/research-methods-methodologies/ textual-research/269-textual-research. 
2 Which in some notable cases is presented as borderline to myth; Federico Soriano, "Gesture," in The Metapolis Dictionary of Advanced Architecture (Barcelona: Actar, 2003), 262.

3 For example, Mitchell Owens, "A Grand Gesture," Architectural Digest, January 1, 2011, http://www.architecturaldigest.com/architecture/2011-02/ralph_ lauren_grand_gesture_article; Nancy Collins, "Dramatic Gesture Above the City," Architectural Digest, January 1, 2008, http://www.architecturaldigest.com/ celebrity-homes/2008/chris-meloni-article.

4 Tom Porter, "Gesture," in Archispeak: An Illustrated Guide to Architectural Terms (London; New York: Spon Press, 2004), 90; Soriano, "Gesture."

5 As it appears explicitly in the French tradition, and especially - as we shall see further on -in the case of the Competition for the Centre Beaubourg. For the social value of these narratives, cf. Roland Barthes, Mythologies, trans. Annette Lavers and Jonathan Cape Ltd. (New York: The Noonday Press; Farrar, Straus and Giroux, 1972). By extension, for the social construction of the practice of architecture, see Dana Cuff, Architecture: The Story of Practice (Cambridge, Massachusetts; London, England: The MIT Press, 1991); "Introduction: Architecture's DoubleBlind," in The SAGE Handbook of Architectural Theory, ed. C. Graig Crysler, Stephen Cairns, and Hilde Heynen (London: SAGE Publications Ltd, 2012), 385-392; Spiro Kostof (ed.), The Architect: Chapters in the History of the Profession (Berkeley and Los Angeles, California: University of California Press, 2000).

6 For example, the preoccupations of Le Corbusier for the Open Hand monument in Chandigarh Le Corbusier, Le Corbusier. Mise au point (Paris: Éditions Forces vives (Impr. I.L.C.), 1966); Le Corbusier and Ivan Žaknić, The Final Testament of Père Corbu: A Translation and Interpretation of Mise Au Point, The Henry McBride Series in Modernism and Modernity (New Haven: Yale University Press, 1997); see also the book cover of Biris (fig.1) Architektonikis Simadia ke didagmata: sto ichnos tis sinthetikis domis [Marks and Teachings in Architecture: Following the traces of the structure of synthesis ] (in Greek) (Athens: MIET (Morfotiko Idryma Ethnikis Trapezis) [Cultural Foundation of the National Bank], 1996); On a wider scope, for a concise account of the hand as a symbol, see Ami Ronnberg and Kathleen Martin, eds., "Hand," in The Book of Symbols: Reflections on Archetypal Images (Köln; London: Taschen, 2010), 380-3.

7 Daniel M. Herbert, "Graphic Processes in Architectural Study Drawings," Journal of Architectural Education (1984-) 46, no. 1 (September 1992): 28, doi:10.2307/1425238; Architectural Study Drawings (John Wiley \& Sons, 1993); Noam Andrews, "The Architectural Gesture," in Log, vol. 33 (New York, NY: Anyone Corporation, 2015), 137-55 Vinod Goel, Sketches of Thought (Cambridge, Mass: MIT Press, 1995); Bryan Lawson, What Designers Know (Oxford, UK: Architectural Press, 2004), chap. 4.

8 Indicatively: Vittorio Gallese and Alessandro Gattara, "Embodied Simulation, Aesthetcs, and Architecture: An Experimental Aesthetic Approach," in Mind in Architecture: Neuroscience, Embodiment, and the Future of Design, ed. Sarah Robinson and Juhani Pallasmaa (Cambridge, Massachusetts: The MIT Press, 2015), 161-80. 


\section{Amps}

9 Bart Verschaffel, Architecture Is (as) a Gesture (Luzern: Quart Verlag, 2001).

10 Ákos Moravánszky, “The Grand Gesture," in Eastmodern (Springer Vienna, 2007), 196-201, http://link.springer.com/chapter/10.1007/978-3-211-71532-1_18.

11 This is attempted in Angelos Psilopoulos, "Draft for a Meta-Theory of Gesture as a Mechanism of Meaning in Architecture: An Inquiry between Myth and Embodied Action," in Architecture and Writing (Archtheo '14 / Theory of Architecture conference, Istanbul: DAKAM Publishing, 2014), 373-84.

12 Per Serres' "quasi-objet"; The Parasite, trans. Lawrence R. Schehr, 1st University of Minnesota Press ed, Posthumanities 1 (Minneapolis: University of Minnesota Press, 2007).

13 Jan Bremmer and Herman Roodenburg, eds., A Cultural History of Gesture: From Antiquity to the Present Day (Cambridge: Polity Press, 1994).

14 Adam Kendon, Gesture: Visible Action as Utterance (Cambridge University Press, 2004); David McNeill, Gesture and Thought (Chicago: University of Chicago Press, 2005).

15 For example, Fondation Louis Vuitton, "A Major Architectural Gesture," accessed April 18, 2016, http://www.fondationlouisvuitton.fr/content/flvinternet/ en/la-fondation/un-geste-architectural-majeur.html.

16 For example, Thomas Silva, "Gesture; Hand Drawings by Architects: Curated by Thomas Silva" (Exhibition, George Lawson Gallery, San Francisco, CA, December 7, 2010),

17 Andrews, "The Architectural Gesture."

18 Willemien Visser and Mary Lou Maher, "The Role of Gesture in Designing," AI EDAM 25, Special Issue 03 (2011): 213-20, doi:10.1017/S0890060411000047.

19 Directly quoting architect Ján Bahna; Moravánszky, “The Grand Gesture," 196.

20 "Un Geste Architectural-Traduction Anglaise - Linguee." Accessed February 19, 2016. http://www.linguee.fr/francais-anglais/traduction/un+geste+architectural. html

21 INALF et ATILF (CNRS, Université Nancy 2), "GESTE : Proxémie de GESTE," Trésor de La Langue Française Informatisé. En Ligne (Centre National de Ressources Textuelles et Lexicales), accessed April 12, 2016, http://www.cnrtl.fr/ proxemie/geste.

22 INALF et ATILF (CNRS, Université Nancy 2), "GESTE : Définition de GESTE ; GESTE [2], Subst. Fém.," Trésor de la Langue Française Informatisé. En Ligne (Centre National de Ressources Textuelles et Lexicales), accessed April 12, 2016, http://www.cnrtl.fr/definition/geste.

23 Sue Collard, "Architectural Gestures and Political Patronage: The Case of the Grands Travaux," International Journal of Cultural Policy 5, no. 1 (1998): $33-47$.

24 (...) and the case of "L'association du Geste Architecturale". See Claude Mollard, L'enjeu Du Centre Georges Pompidou, 10/18; 1104 (Paris: Union générale d'éditions, 1976), 76-80.

25 As it is pointed out very acutely in the corresponding article in the Encyclopaedia Universalis. Daniel Charles, "ARCHITECTURE (Thèmes Généraux) Architecture et Philosophie," Encyclopadia Universalis [En Ligne] (Encyclopædia 
Universalis France S.A.), accessed July 11, 2016, http://www.universalis.fr/ encyclopedie/architecture-themes-generaux-architecture-et-philosophie/.

26 (...) now known as the Centre Georges Pompidou (CGP).

27 Which was favourable to the choices of the Jury and the general context of the competition.

28 "Le geste architectural traduit la raison et les sentiments de l'architecte par un tracé dans l'espace. Il donne le caractère à l'œuvre. Une œuvre sans ce geste n'est pas œuvre d'architecture". André Bergerioux, "Geste architectural," Le Nouvel Observateur, February 14, 1972, sec. Courrier (p. 3).

29 (...) albeit following two other arguments attacking technical and legal aspects of the procedure of the competition, particularly the function of the president of the committee Jean Prouvé. It was on these grounds that the Association filed a legal complaint which actually delayed the construction of the CGP for several years.

30 President of the Jury Prouvé had publicly confessed this disposition: "[a]ssez rapidement, se révéla une sorte d"allergie" à ce que l'on pourrait qualifier de "grand geste architectural prestigieux." ([v]ery quickly, a sort of allergy was revealed against what might qualify as a prestigious grand architectural gesture.) Jean Prouvé, "Centre Beaubourg. Notes Pour la Conférence de Presse," Délibérations et Rapport Du Jury, July 1971, 2, 1992037/009 (1970-1973); Jugement et résultats du concours: art 8-29 (1970-1973), Archives Centre Georges Pompidou.

31 "Faut-il estimer que sont les plus mauvaises raisons du monde le fait que des citoyens de toutes professions et de tous niveaux sociaux se soient groupés en une association dite «le Geste architectural», en raison de leur inquiétude devant une instance officielle avouant son allergie pour les gestes architecturaux et sa seule confiance dans la technique et la programmation où doit se faire le moule de l'homme- robot de l'an 2000. Faut-il un homme adapté au progrès institué en « veau d'or et au processus économique de production et de consommation? Faut-il aussi pour cet idéal, pour asservir l'homme à la machine, protéger la pollution architecturale?" Bergerioux, "Geste architectural."

32 As it was expressed by Jacques Chirac at the National Assembly on December 3, 1974: "Le Centre doit mettre ses trésors à la disposition du plus grand nombre, à commencer par les jeunes et par ceux ou celles qui travaillent. Des dispositions originales lui permettront de remplir cette mission dont je puis attester qu'elle était essentielle aux yeux du président Pompidou." Mollard, L'enjeu du Centre Georges Pompidou, 262; see also Louis Pinto, "Déconstruire Beaubourg: art, politique et architecture," Genèses 6, no. 1 (1991): 99, doi:10.3406/genes.1991.1094; The notion of "democratization" was already integral to the official framework for cultural policy by the Decree No 59-889/ July 24, 1959, concerning the organization of the Ministry of Cultural Affairs (art.1). As mentioned in Mireille Gaüzère, "Le Centre Georges Pompidou," in Culture et action chez Georges Pompidou: actes du colloque, Paris, 3 et 4 décembre 1998, ed. Jean-Claude Groshens et al., 1re éd, Politique d'aujourd'hui (Paris: Presses universitaires de France, 2000), 414-15.

33 "Le défi de Beaubourg. Beaubourg's defiance," L'Architecture d'aujourd'hui, 1977, 46; see also Laurent Fleury, Le Cas Beaubourg: Mécénat D'état et Démocratisation de La Culture (Paris: Armand Colin, 2007), 58. 


\section{Amps}

34 The significance of this system's thinking to the project is discussed extensively by Ewan Branda in his PhD thesis. Ewan Branda, "The Architecture of Information at Plateau Beaubourg" (Ph.D., Architecture 0084 UCLA, University of California, Los Angeles, 2012), UCLA Electronic Theses and Dissertations, http://www. escholarship.org/uc/item/0ww309s3; For a general overview of Lombard's principal views on the merits of programming, see François Lombard, "La programmation en architecture et urbanisme," L'Architecture d'aujourd'hui, 1972; for a brief and precise historical account, see Fleury, Le Cas Beaubourg, 54-9.

35 Mireille Gaüzère, "Le Centre Georges Pompidou," 426.

36 Fleury, Le Cas Beaubourg, 62.

37 Pinto, "Déconstruire Beaubourg," 109.

38 (...) who substituted Jørn Utzon because the latter was unable to participate "for reasons of health." "Edition du rapport définitif du Jury," Délibérations et rapport du Jury, 1972, 3, 1992037/009 (1970-1973); Jugement et résultats du concours: art 8-29 (1970-1973), Archives Centre Georges Pompidou.

39 Notice du Petit Journal (CCI, Centre Georges-Pompidou) published on the occasion of an exhibition dedicated to Jean Prouvé in 1990. As noted in Pinto, "Déconstruire Beaubourg," 110; In the Final Report of the Jury, Prouvé is refered to as an architect, although he was never officially part of the Society of French Architects. "Edition du rapport définitif du Jury," 4 This became one of the principal arguments of the opposition, attacking the legitimacy of the Jury and therefore the whole process.

40 Liebhaers and Sandberg being the obvious two of the lot.

41 Fleury, Le Cas Beaubourg, 59.

42 Ibid., 60.

43 Herman Liebaers, Mostly in the Line of Duty: Thirty Years with Books (Dordrecht: Springer Netherlands, 1980), 99, http://dx.doi.org/10.1007/978-94-009-8802-6. In the same passage, Liebaers confesses his own disenvowment against an architect 'standing between the exhibited works of art and the visitors', specifically attacking the Guggenheim Museum in New York and its architect, Frank Lloyd Wright. As he says, "[t]he Centre Pompidou aimed at exactly the contrary and was nearly as successful in reaching its aim" (ibid.).

44 Most vividly expressed in the work of Yona Friedman, or discussed by Michel Ragon or Victor Vasarely. Larry Busbea, Topologies: The Urban Utopia in France, 1960-1970 (Cambridge, Mass: MIT Press, 2007); see also, Claude Massu, "Le Centre Pompidou: Des Utopies à leur Programmation," in Centre Pompidou, Trente Ans d'histoire, ed. Centre Georges Pompidou and Dufrêne (Paris: Editions du Centre Pompidou, 2007), 123-34; It is also worth noting that Vasarely did the iconic portrait of President Pompidou that stood hanging at the main entrance hall of the Centre. Victor Vasarely, Hommage à Georges Pompidou (Portrait-Relief Recto/Verso), 38 profilés d'aluminium disposés verticalement et échancrés, 1976, AM 1976-1141, National Museum of Modern Art/ Industrial Design Centre / CGP.

45 "Il y avait une totale unanimité à ce sujet; une volonté d'éliminer tout pastiche ou toute architecture d'accompagnement dont nous connaissions les résultats néfastes." (There was complete unanimity on this subject; a willingness to 


\section{Amps}

eliminate pastiche or any accompanying architecture whose harmful consequences we were familiar with.) Hélène Demoriane, Jean Prouvé, la permanence d'un choix, Interview: L'Architecture d'aujourd'hui 187:48-9, 1977.

46 (...) given that the competition received no less than 681 projects. "Edition du rapport définitif du Jury," 1.

47 Ibid., 17; A representative variety of the submissions is presented in Susan Holden, "Possible Pompidous," AA Files, no. 70 (2015): 33-45, http://www.jstor.org/ stable/43432925.

48 "Edition du rapport définitif du Jury," 17-18.

49 “(...) si la liberté des formes architecturales doit être encouragée, cette liberté ne peut être simplement formelle ; qu'un 'monument' qui n'aurait d'autre fonction, que d'exprimer un 'geste' architectural est vain ; que l'emphase n'est pas l'éloquence et que l'art pour l'art peut être le contraire de l'art." Ibid., 18; This passage was also mentioned several times in the press (hence our characterization "famously"). See e.g., "Le défi de Beaubourg. Beaubourg's defiance," 46-7.

50 (...) who was, in fact, one of the first to enter, as the number of his submission indicates: "Projet 006 ".

51 The building is referred to as a "bâtiment-sculpture" by its author on several occasions. André Bergerioux, "Exposé Général sur le Parti Architectural par Rapport à la Philosophie du Centre; General Account of the Architectural Concept in Relation to the Philosophy of the Center," Submission, Concours International d'idées pour la Réalisation du Centre du Plateau Beaubourg (Paris: Délégation à la réalisation du Centre du Plateau Beaubourg, 1970), 1992037/016 (Juillet 1971); Dossiers des projets non primés: art 8-29 (1970-1973), Archives Centre Georges Pompidou.

52 "Concevoir un centre culturel, c'est répondre à certains impératifs matériels, sans doute, mais c'est surtout mettre la matière au service d'une idée. (...) Ce projet veut être, plus qu'un bâtiment, un monument. Si la ligne générale de l'élément central évoque celle d'une main, c'est en raison de sa valeur symbolique sans doute, toute création passant par elle, mais aussi de sa beauté sculpturale. Quelle autre forme aurait pu mieux traduire ce qui fait l'unité entre les multiples formes de la création? (...) Mais un symbole risquait d'être froid. Il fallait l'animer. Ce sont les arbres et les plantes qui, faisant corps avec l'architecture et les œuvres des artistes, donnent sa vie au centre. (...) Une sculpture au-dessus de l'eau, sur un socle de verdure, telle est la réponse de la matière à la question posée par la philosophie du centre Beaubourg." Ibid.

53 For which Le Corbusier had fought long and hard to realize. Despite his efforts, the monument was actually realized in 1985, twenty years after Le Corbusier's death. Nevertheless, the concept was advertised in a sketch that Le Corbusier created for a celebratory volume on the occasion of the 75th anniversary of Nehru's birth in 1964. Le Corbusier and Žaknić, The Final Testament of Père Corbu, 10-14.

54 A general sketch of such influences, for all of the submissions, is traced in Holden, "Possible Pompidous."

55 "This symbol, which has preoccupied me and my subconscious for many years now (...)" Le Corbusier and Žaknić, The Final Testament of Père Corbu, 97. 


\section{Amps}

56 Ibid., 10-14; It should also be noted here that Le Corbusier was not getting any commissions at the time. As Claude Mollard remembers it, " (...) it took his death for his talent to be recognized (...)" by the authorities representing the State at the time. Mollard, L'enjeu du Centre Georges Pompidou, 33.

57 Around 1958 Minister of Culture André Malreaux had come up with an idea for a "Musée du XXe siècle", aiming to push France back into the international cultural scene. The project was offered to Le Corbusier, for whom Malreaux had great admiration. Nevertheless, in an interview with Sylvain Zegel for the Figaro littéraire (Sep. 28, 1965), Le Corbusier protested that the site - la Défense - was too far out of the city, and that "for a museum to be truly open to everyone, it should be built in the very heart of the city". Mireille Gaüzère, "Le Centre Georges Pompidou," 421; see also Mollard, L'enjeu du Centre Georges Pompidou, 108-9; Bernadette Dufrêne, La création de Beaubourg, Collection Événements (Grenoble: Presses Universitaires de Grenoble, 2000), 33.

58 See Stanislaus von Moos, "The Politics of the Open Hand: Notes on Le Corbusier and Nehru at Chandigarh," in The Open Hand: Essays on Le Corbusier, ed. Russell Walden (Cambridge: MIT Press, 1977), 412-57 Von Moos argues eventually that Chandigarh presents us with a case of convergence between political ideology and Le Corbusier's ideas. Nevertheless, this point is attacked by William J. Curtis who stresses the dimension of Le Corbusier's personal expression in the venture. "The Open Hand. Essays on Le Corbusier Russell Walden [Review]," Journal of the Society of Architectural Historians 37, no. 4 (December 1978): 298, doi:10.2307/989246.

59 As Le Corbusier writes in his Mise au Point: "This Open Hand, a symbol of peace and reconciliation, must be erected in Chandigarh. This symbol, which has preoccupied me and my subconscious for many years now, ought to be realized, to bear witness to harmony. (...)" Le Corbusier and Žaknić, The Final Testament of Père Corbu, 97; see also Zaknic's account: ibid., 10-14.

60 Or, as Claude Mollard remembers it in his Prologue, "[t]he architect is no more the grand maître of the city. His intervention is founded in the group, and among other actors." Mollard, L'enjeu du Centre Georges Pompidou, 15.

61 Dufrêne, La création de Beaubourg, 19-20; see also Mireille Gaüzère, "Le Centre Georges Pompidou," 418-19.

62 Georges Pompidou, Déclarations sur l'art et l'architecture recueillies, Le Monde, October 17, 1972, PoliText: Base de données de discours politiques français (17892002) / Entretiens et discours, http://bcl.unice.fr/politext/

63 "Paris is renewed - some say "destroyed" - by means of new constructions that inevitably alter its character. How can we reconcile the dynamism of innovation and the necessity to save the best part of the old Paris, [which is] by definition irreplaceable?"

64 The importance of the term "monument" to President Pompidou is best discussed in: Fleury, Le Cas Beaubourg, 63-6; see also Liebaers, Mostly in the Line of Duty Thirty Years with Books, 100.

65 "Old Paris is no more, the form of a city/Changes more quickly, alas!, than the heart of a mortal." 


\section{Amps}

66 Pompidou, Déclarations sur l'art et l'architecture recueillies.

67 Most explicitly: Fleury, Le Cas Beaubourg, 45-154; Mireille Gaüzère, "Le Centre Georges Pompidou," 423-28; see also: Mollard, L'enjeu Du Centre Georges Pompidou, 261-63; Robert Bordaz, Le Centre Pompidou: Une Nouvelle Culture (Paris: Ramsay, 1977), 70-76.

68 "The Pompidoleum," The Architectural Review, May 1977.

69 Axel Gryspeerdt, "Le Centre et la Caricature: Quand le Dessin de Presse Participe de la Polémique," in Centre Pompidou, Trente Ans D'histoire, ed. Bernadette Dufrêne (Paris: Editions du Centre Pompidou, 2007), 150-1.

70 "At the origins of an act of architecture, especially if it concerns an institution of great dimensions, lies inevitably the decision of an authority, even that of a single person," Mollard, L'enjeu du Centre Georges Pompidou, 262-3.

71 According to the recollection of Robert Bordaz: "comme il le disait en riant, 'n'est-ce pas, il faut crier !' Bordaz, Le Centre Pompidou, 71.

72 Flusser, Vilém. Gestures. Translated by Nancy Ann Roth. Minneapolis; London: University of Minnesota Press, 2014. http://www.upress.umn.edu/book-division/ books/gestures

73 Christian Gänshirt, “Gesture.” Tools for Ideas: An Introduction to Architectural Design, 105-11(106). Basel; Boston; Berlin: Birkhäuser GmbH, 2007.

74 Verschaffel, Architecture Is (as) a Gesture.

75 Henry van de Velde, Pages de doctrine (Bruxelles: La Maison du Poète, 1942); as cited in Verschaffel, Architecture Is (as) a Gesture.

76 Alan Prohm, "Form and Structure Reframed: A new 'On the Cult of the New in Our Century,"” ed. Andrew Levy, Crayon 5 (2007): 191.

77 Ibid., 195.

78 Verschaffel, Architecture Is (as) a Gesture, 29.

79 Ibid.

80 David Looseley, "A Certain Idea of the City: The Presidential grands projects," in The Politics of Fun: Cultural Policy and Debate in Contemporary France, David Looseley (Oxford [England]; New York: Berg Publishers, 1997), 135-54.

81 Susan Collard argues that "[t]he renewal of a close relationship between political power and culture became a distinctive feature of the Fifth Republic". "French Cultural Policy: The Special Role of the State," in Contemporary French Cultural Studies, ed. William Kidd and Sian Reynolds (London; New York: Arnold; Oxford University Press, 2000), 42.

82 For a critical account on either (but especially the former), see: Jean Baudrillard, L'effet Beaubourg: Implosion et Dissuasion, Débats (Paris: Éditions Galilée, 1977); Also see Marie Leroy, Le Phénomène Beaubourg, Combat Culturel 3 (Syros, 1977); Reyner Banham, "Enigma of the Rue Du Renard [Criticism]," The Architectural Review, May 1977; For a retrospective and personal account, see Jean Nouvel, in Jean Baudrillard and Jean Nouvel, The Singular Objects of Architecture (Minneapolis: University of Minnesota Press, 2002), 40.

83 For example, Bruno Latour, Reassembling the Social: An Introduction to ActorNetwork-Theory, Clarendon Lectures in Management Studies (Oxford; New York: Oxford University Press, 2005); see also An Inquiry into Modes of Existence: 


\section{Amps}

An Anthropology of the Moderns (Cambridge, Massachusetts: Harvard University Press, 2013).

84 Michel Serres, The Parasite, trans. Lawrence R. Schehr, 1st University of Minnesota Press ed, Posthumanities 1 (Minneapolis: University of Minnesota Press, 2007), 225.

85 Serres, The Parasite, 225.

86 Hans-Georg Gadamer, Truth and Method, trans. Joel Weinsheimer and Donald G. Marshall, First paperback edition. translation revised by Joel Weinsheimer and Donald G. Marshall, The Bloomsbury Revelations Series (London: Bloomsbury, 2013), 27-31

87 Anne Cauquelin, Essai d'une Philosophie Urbaine (Paris: Presses Universitaires de France, 1982). 176; as cited in Verschaffel, Architecture Is (as) a Gesture, 25.

88 Most notably, Willemien Visser. See, e.g., The Cognitive Artefacts of Designing (Mahwah, New Jersey: Lawrence Erlbaum Associates, Publishers, 2006); Willemien Visser and Mary Lou Maher, 'The Role of Gesture in Designing', AI EDAM 25, no. Special Issue 03 (2011): 213-20, doi:10.1017/S0890060411000047.

\section{Bibliography}

Andrews, Noam. "The Architectural Gesture." Log, 33 (2015): 137-55.

Banham, Reyner. "Enigma of the Rue Du Renard [Criticism]." The Architectural Review (May 1977).

Barthes, Roland. Mythologies. Translated by Annette Lavers and Jonathan Cape Ltd. New York: The Noonday Pess; Farrar, Straus and Giroux, 1972.

Baudrillard, Jean. L'effet Beaubourg: Implosion et Dissuasion. Débats. Paris: Éditions Galilée, 1977.

Baudrillard, Jean, and Jean Nouvel. The Singular Objects of Architecture. Minneapolis: University of Minnesota Press, 2002.

Bergerioux, André. "Exposé Général Sur Le Parti Architectural par Rapport à la Philosophie du Centre; General Account of the Architectural Concept in Relation to the Philosophy of the Center." Submission. Concours International d'idées pour la Réalisation du Centre du Plateau Beaubourg. Paris: Délégation à la réalisation du Centre du Plateau Beaubourg, 1970. 1992037/016 (Juillet 1971); Dossiers des projets non primés: art 8-29 (1970-1973). Archives Centre Georges Pompidou.

Bergerioux, André. "Geste architectural.” Le Nouvel Observateur, February 14, 1972, sec. Courrier (p. 3).

Biris, Tasos K. Architektonikis Simadia ke didagmata: sto ichnos tis sinthetikis domis [Marks and Teachings in Architecture: following the traces of the structure of synthesis] (in greek). Athens: MIET (Morfotiko Idryma Ethnikis Trapezis) [Cultural Foundation of the National Bank], 1996.

Bordaz, Robert. Le Centre Pompidou: Une Nouvelle Culture. Paris: Ramsay, 1977.

Branda, Ewan. "The Architecture of Information at Plateau Beaubourg." Ph.D., Architecture 0084 UCLA, University of California, Los Angeles, 2012. UCLA Electronic Theses and Dissertations. Accessed November 24, 2017. http://www. escholarship.org/uc/item/0ww309s3. 


\section{Amps}

Bremmer, Jan, and Herman Roodenburg, eds. A Cultural History of Gesture: From Antiquity to the Present Day. Cambridge: Polity Press, 1994.

Busbea, Larry. Topologies: The Urban Utopia in France, 1960-1970. Cambridge, Mass: MIT Press, 2007.

Cauquelin, Anne. Essai D'une Philosophie Urbaine. Paris: Presses universitaires de France, 1982.

Charles, Daniel. "ARCHITECTURE (Thèmes Généraux) - Architecture et Philosophie." Encyclopadia Universalis [En Ligne]. Encyclopædia Universalis France S.A. Accessed July 11, 2016. http://www.universalis.fr/encyclopedie/ architecture-themes-generaux-architecture-et-philosophie/.

Collard, Sue. "Architectural Gestures and Political Patronage: The Case of the Grands Travaux." International Journal of Cultural Policy 5, no. 1 (1998): 33-47.

Collard, Susan. "French Cultural Policy: The Special Role of the State." In Contemporary French Cultural Studies, edited by William Kidd and Sian Reynolds, 38-50. London; New York: Arnold; Oxford University Press, 2000.

Collins, Nancy. "Dramatic Gesture Above the City." Architectural Digest, January 1, 2008. Accessed November 24, 2017. http://www.architecturaldigest.com/ celebrity-homes/2008/chris-meloni-article.

Cuff, Dana. Architecture: The Story of Practice. Cambridge, Massachusetts; London, England: The MIT Press, 1991.

Cuff, Dana. "Introduction: Architecture's Double-Blind." In The SAGE Handbook of Architectural Theory, edited by C. Graig Crysler, Stephen Cairns, and Hilde Heynen, 385-92. London: SAGE Publications Ltd, 2012.

Curtis, William J. R. "The Open Hand. Essays on Le Corbusier Russell Walden. [Review]." Journal of the Society of Architectural Historians 37, no. 4 (December 1978): 295-9. doi:10.2307/989246.

Demoriane, Hélène. "Jean Prouvé, la permanence d'un choix." Interview: L'Architecture d'aujourd'hui 187: 48-9, 1977.

Dufrêne, Bernadette. La création de Beaubourg. Collection Événements. Grenoble: Presses Universitaires de Grenoble, 2000.

"Edition du rapport définitif du Jury." Délibérations et rapport du Jury, 1972. 1992037/009 (1970-1973); Jugement et résultats du concours: art 8-29 (19701973). Archives Centre Georges Pompidou.

Elo, Satu, Maria Kääriäinen, Outi Kanste, Tarja Pölkki, Kati Utriainen, and Helvi Kyngäs. "Qualitative Content Analysis.” SAGE Open 4, no. 1 (January 1, 2014): 2158244014522633. doi:10.1177/2158244014522633.

Fairclough, Norman. Analysing Discourse: Textual Analysis for Social Research. London; New York: Routledge, 2003.

Fleury, Laurent. Le Cas Beaubourg: Mécénat D'état et Démocratisation de La Culture. Paris: Armand Colin, 2007.

Flusser, Vilém. Gestures. Translated by Nancy Ann Roth. Minneapolis; London: University of Minnesota Press, 2014.

Fondation Louis Vuitton. “A Major Architectural Gesture.” Accessed April 18, 2016. http://www.fondationlouisvuitton.fr/content/flvinternet/en/la-fondation/un-gestearchitectural-majeur.html. 


\section{Amps}

Gadamer, Hans-Georg. Truth and Method. Translated by Joel Weinsheimer and Donald G. Marshall. First paperback edition.translation revised by Joel Weinsheimer and Donald G. Marshall. The Bloomsbury Revelations Series. London: Bloomsbury, 2013.

Gallese, Vittorio, and Alessandro Gattara. "Embodied Simulation, Aesthetcs, and Architecture: An Experimental Aesthetic Approach.” In Mind in Architecture: Neuroscience, Embodiment, and the Future of Design, edited by Sarah Robinson and Juhani Pallasmaa, 161-80. Cambridge, Massachusetts: The MIT Press, 2015.

Gänshirt, Christian. “Gesture.” In his Tools for Ideas: An Introduction to Architectural Design, 105-11(106). Basel; Boston; Berlin: Birkhäuser GmbH, 2007.

Gaüzère, Mireille. "Le Centre Georges Pompidou." In Culture et action chez Georges Pompidou: actes du colloque, Paris, 3 et 4 décembre 1998, edited by JeanClaude Groshens et al., 1re éd, Politique d'aujourd'hui, 414-15. Paris: Presses universitaires de France, 2000.

Goel, Vinod. Sketches of Thought. Cambridge, Mass: MIT Press, 1995.

Grimmer, Justin, and Brandon M. Stewart. "Text as Data: The Promise and Pitfalls of Automatic Content Analysis Methods for Political Texts." Political Analysis, January 22, 2013, mps028. doi:10.1093/pan/mps028.

Gryspeerdt, Axel. "Le Centre et la Caricature: Quand le Dessin de Presse Participe de la Polémique." In Centre Pompidou, Trente Ans D'histoire, edited by Bernadette Dufrêne, 150-1. Paris: Editions du Centre Pompidou, 2007.

Herbert, Daniel M. Architectural Study Drawings. John Wiley \& Sons, 1993.

Herbert, Daniel M. "Graphic Processes in Architectural Study Drawings." Journal of Architectural Education (1984-) 46, no. 1 (September 1992): 28. doi:10.2307/1425238.

Holden, Susan. "Possible Pompidous." AA Files, no. 70 (2015): 33-45. http://www. jstor.org/stable/43432925.

INALF et ATILF (CNRS, Université Nancy 2). "GESTE : Définition de GESTE; GESTE [2], Subst. Fém." Trésor de la Langue Française Informatisé. En Ligne. Centre National de Ressources Textuelles et Lexicales. Accessed April 12, 2016. http://www.cnrtl.fr/definition/geste.

INALF et ATILF “GESTE : Proxémie de GESTE.” Trésor de la Langue Française Informatisé. En Ligne. Centre National de Ressources Textuelles et Lexicales. Accessed April 12, 2016. http://www.cnrtl.fr/proxemie/geste.

Kendon, Adam. Gesture: Visible Action as Utterance. New York: Cambridge University Press, 2004.

Kostof, Spiro, ed. The Architect: Chapters in the History of the Profession. Berkeley and Los Angeles, California: University of California Press, 2000.

Latour, Bruno. Reassembling the Social: An Introduction to Actor-Network-Theory. Clarendon Lectures in Management Studies. Oxford; New York: Oxford University Press, 2005.

Latour, Bruno. An Inquiry into Modes of Existence: An Anthropology of the Moderns. Cambridge, Massachusetts: Harvard University Press, 2013.

Lawson, Bryan. What Designers Know. Boston: Elsevier/Architectural Press, 2004.

Le Corbusier. Le Corbusier. Mise au point. Paris: Éditions Forces vives (Impr. I.L.C.), 1966. 


\section{Amps}

Le Corbusier, and Ivan Žaknić. The Final Testament of Père Corbu: A Translation and Interpretation of Mise Au Point. The Henry McBride Series in Modernism and Modernity. New Haven: Yale University Press, 1997.

"Le défi de Beaubourg. Beaubourg's defiance." L'Architecture d'aujourd'hui 189 (1977): 40-81.

Leroy, Marie. Le Phénomène Beaubourg. Combat Culturel 3. Paris: Syros, 1977.

Liebaers, Herman. Mostly in the Line of Duty: Thirty Years with Books. Dordrecht: Springer Netherlands, 1980. http://dx.doi.org/10.1007/978-94-009-8802-6.

Lombard, François. "La programmation en architecture et urbanisme.” L'Architecture d'aujourd'hui 44, no. 160 (1972): 4-10.

Looseley, David. The Politics of Fun: Cultural Policy and Debate in Contemporary France. Oxford: Berg Publishers, 1995.

Massu, Claude. "Le Centre Pompidou: Des Utopies à Leur Programmation." In Centre Pompidou, Trente Ans D'histoire, edited by Centre Georges Pompidou and Bernadette Dufrêne, 123-34. Paris: Editions du Centre Pompidou, 2007.

McKee, Alan. Textual Analysis: A Beginner's Guide. London, United Kingdom: SAGE Publications Ltd, 2003. http://srmo.sagepub.com/view/textual-analysis/ SAGE.xml.

McNeill, David. Gesture and Thought. Chicago: University of Chicago Press, 2005.

Mireille Gaüzère. "Le Centre Georges Pompidou." In Culture et action chez Georges Pompidou: actes du colloque, Paris, 3 et 4 décembre 1998, edited by Jean-Claude Groshens, Jean-François Sirinelli, Noëlline Castagnez-Ruggiu, and Association Georges Pompidou, 1re éd., 413-27. Politique d'aujourd'hui. Paris: Presses universitaires de France, 2000.

Mollard, Claude. L'enjeu du Centre Georges Pompidou. Paris: Union générale d'éditions, 1976.

Moos, Stanislaus von. "The Politics of the Open Hand: Notes on Le Corbusier and Nehru at Chandigarh." In The Open Hand: Essays on Le Corbusier, edited by Russell Walden, 412-57. Cambridge: MIT Press, 1977.

Moravánszky, Ákos. "The Grand Gesture.” In Eastmodern, edited by Hertha Hurnaus, Benjamin Konrad, and Maik Novotny, 196-201. Springer Vienna, 2007. http://link.springer.com/chapter/10.1007/978-3-211-71532-1_18.

Moxley, Joseph M. "Textual Research - Writing Commons.” Accessed July 3, 2014. http://www.writingcommons.org/open-text/research-methods-methodologies/ textual-research/269-textual-research.

Owens, Mitchell. “A Grand Gesture.” Architectural Digest, January 1, 2011. https:// www.architecturaldigest.com/story/ralph-lauren-grand-gesture-article

Pinto, Louis. "Déconstruire Beaubourg : art, politique et architecture." Genèses 6, no. 1 (1991): 98-124. doi:10.3406/genes.1991.1094.

Pompidou, Georges. Déclarations sur l'art et l'architecture recueillies. Le Monde, October 17, 1972. PoliText: Base de données de discours politiques français (1789-2002) / Entretiens et discours. http://bcl.unice.fr/politext/

Porter, Tom. "Gesture." In his Archispeak, An Illustrated Guide to Architectural Terms, 90. London; New York: Spon Press, 2004. 


\section{Amps}

Prohm, Alan. "Form and Structure Reframed: A New 'On the Cult of the New in Our Century." Edited by Andrew Levy. Crayon 5 (2007): 185-211. https://alanprohm. wordpress.com/writings/.

Prouvé, Jean. "Centre Beaubourg. Notes Pour la Conference de Presse.” Délibérations et Rapport du Jury, July 1971. 1992037/009 (1970-1973); Jugement et résultats du concours: art 8-29 (1970-1973). Archives Centre Georges Pompidou.

Psilopoulos, Angelos. "Draft for a Meta-Theory of Gesture as a Mechanism of Meaning in Architecture: An Inquiry between Myth and Embodied Action." In Architecture and Writing, 373-84. Istanbul: DAKAM Publishing, 2014.

Ronnberg, Ami, and Kathleen Martin, eds. "Hand." In The Book of Symbols: Reflections on Archetypal Images, 380-83. Köln; London: Taschen, 2010.

Serres, Michel. The Parasite. Translated by Lawrence R. Schehr. Posthumanities 1. Minneapolis: University of Minnesota Press, 2007.

Silva, Thomas. "Gesture; Hand Drawings by Architects: Curated by Thomas Silva." Exhibition, George Lawson Gallery, San Francisco, CA, December 7, 2010. http:// www.georgelawsongallery.com/exhibitions_10.html.

Soriano, Federico. "Gesture." In The Metapolis Dictionary of Advanced Architecture, 262. Barcelona: Actar, 2003.

"The Pompidoleum." The Architectural Review, May 1977.

Vasarely, Victor. Hommage À Georges Pompidou (Portrait-Relief Recto/Verso). 38 profilés d'aluminium disposés verticalement et échancrés, 1976. AM 1976-1141. National museum of modern art/ Industrial Design Centre / CGP.

Velde, Henry van de. Pages de doctrine. Bruxelles: La Maison du Poète, 1942.

Verschaffel, Bart. Architecture Is (as) a Gesture. Luzern: Quart Verlag, 2001.

Visser, Willemien. The Cognitive Artefacts of Designing. Mahwah, New Jersey: Lawrence Erlbaum Associates, Publishers, 2006.

Visser, Willemien, and Mary Lou Maher. "The Role of Gesture in Designing." $A I$ EDAM 25. Special Issue 03 (2011): 213-20. doi:10.1017/S0890060411000047. 